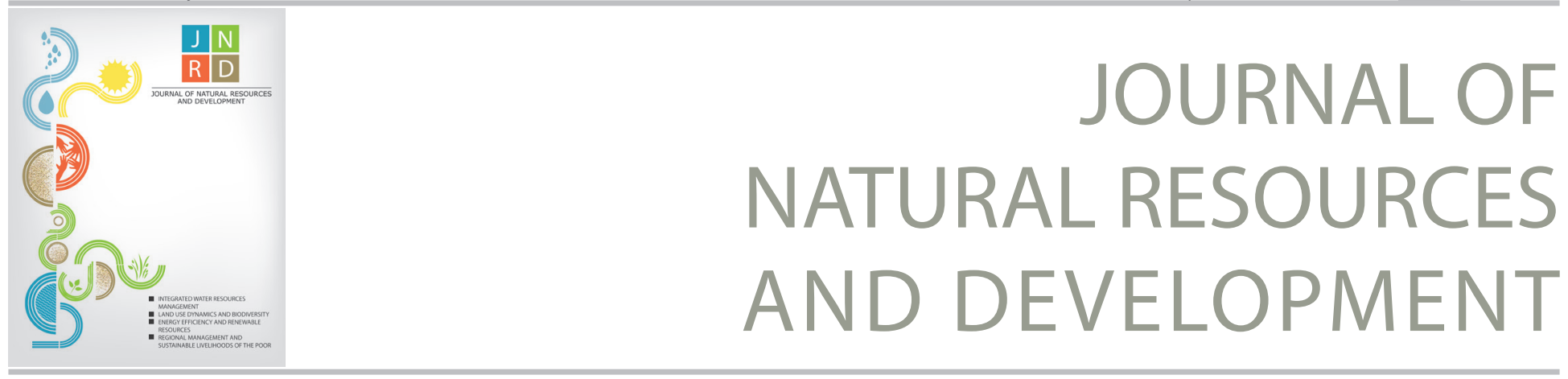

Case study

\title{
Analysis of Aquifer Pumping Test Data to Determine Deep Groundwater Security in Southeastern Bangladesh
}

\author{
Anwar Zahid abd*, M Hazrat Ali c, Farhana Islam ${ }^{e}$, M. Rashidul Hassan ${ }^{c}$, Kamrul Islam ${ }^{c}$, Nur Ahmed ${ }^{f}$ \\ ${ }^{a}$ Ground Water Hydrology, Bangladesh Water Development Board, 72-Green Road, Dhaka-1215, Bangladesh \\ ${ }^{b}$ Department of Geology, University of Dhaka, Nilkhet Rd, Dhaka 1000, Bangladesh \\ ' Institute of Water Modelling (IWM), Road \# 32, New DOHS, Mohakhali Dhaka 1206, Bangladesh \\ ${ }^{d}$ Center for Water and Environment (CWE), 61 Main Road, Mehedibagh, Adabor, Dhaka, Bangladesh \\ e Bangladesh Atomic Energy Commission, Agargaon, Dhaka-1207, Bangladesh \\ 千 University of Florida, Tallahassee, FL 32306, Florida, USA
}

* Corresponding author: anwarzahidb@gmail.com

\section{Article history}

Received 30/04/2018

Accepted 19/09/2018

Published 01/12/2018

\section{Keywords}

Deep groundwater

Aquifer pump test

Saline water encroachment

Safe yield

Confined aquifer

\section{Abstract}

In southeastern Bangladesh, where water quality in the upper aquifers is a serious constraint, future development will likely be confined to deep fresh groundwater. Owing to the importance and pervasive use of deep groundwater, the sustainability of water use has received extensive attention. However, excessive extraction from deep aquifers may pose a threat to the storage as well as the quality of water due to the high susceptibility to salinization and arsenic contamination from upper aquifers. Hence, determining the extension of aquifer units and the characterizing aquifer sediments are very important to ensure sustainable development and management of limited fresh groundwater resources. The study area extends over six districts of the southeastern coastal region of Bangladesh. In order to assess and monitor deep fresh groundwater potential in the study area, aquifer pumping tests were performed at six locations with up to $72 \mathrm{~h}$ of constant-discharge prior to recovery. Different methods were used to analyze the drawdown and recovery data considering aquifers as confined or leaky-confined. Based on transmissivity values it was found that the studied deep aquifers have moderate to high potential for potable water supply. However, this deep fresh groundwater may not be safe for a longer period where upper aquifer units contain saline groundwater and where there is no significant aquitard encountered above or below the deep aquifer. Irrigation extraction of the deep groundwater is not recommended.

(c) 2018 This is an open access article under the CC BY-NC-ND license (http://creativecommons.org/licenses/bync-nd/4.0/). 


\section{Introduction}

Providing sustainable fresh water for domestic use and agriculture irrigation is one of the great challenges in the coastal belt of Bangladesh. The most widespread threat across the coastal belt is not the fall in groundwater quantity but the degraded water quality resulting from high levels of arsenic in shallow groundwater and salt content in upper aquifers [1], [2]. In the coastal belt, potable water is mainly derived from deep aquifers and surface water bodies while irrigation is limited to surface water bodies. Fresh groundwater is also available at shallow aquifer pockets which are replenished by seasonal precipitation during monsoons but which generally turn brackish in the dry season. There is also high vulnerability to salinization of this shallow aquifer due to heavy pumping-induced mixing of preexisting fresh and saline groundwater and due to vertical infiltration of saltwater during periodic storm surge flooding. Rising sea levels would cause the tidal saltwater wedge to intrude further upstream in rivers, potentially resulting in intrusion of salinity to coastal shallow groundwater. Therefore, the deep aquifers $(>250 \mathrm{~m}$ ) in the coastal belt are of strategic value for water supply, health and economic development. Heavy pumping may induce the downward migration of arsenic and saline water in some parts of Bangladesh and in coastal regions, respectively, as many previous studies have shown that intensive exploitation has negative environmental impacts, including a decline in the groundwater table and water quality degradation [3]-[7]. Water quality degradation due to induced leakage may not become apparent for decades after intensive withdrawal of groundwater by pumping has begun [8]. In the study area of southeastern Bangladesh where availability of fresh and safe water is a significant problem in upper aquifers, assessment and monitoring of deep fresh groundwater for its security is of utmost importance. There is little evidence of modern recharge or widespread downward movement of shallow groundwater into the deeper aquifers [9], [10]. The deeper groundwater is not subject to recent recharge [9], [11], [12] and therefore effective assessment and monitoring is required to manage extraction, prepare water allocation plans and to ensure substantial groundwater extraction from deep aquifers for decades or centuries to come [13]. The quantitative analysis of groundwater flow involves understanding the range and variability of key hydraulic parameters. In this study, deep aquifer pumping tests were performed at six locations in order to determine the hydraulic properties of the aquifers. The tests also provide information about the yield and drawdown of the well and other basic information for the solution of many regional and local groundwater flow problems. These data are used to determine the potential of aquifers for pumping, the specific capacity or the discharge-drawdown relation of the well, the zone of influence that is also important to determine correct spacing, the observation of any change of water quality during pumping, etc. As salinity is a major problem in the study areas, the response of salinity intrusion to pumping was monitored during the tests.

\section{Methods}

The constant-discharge deep aquifer pumping tests were performed at six locations for a time period of 36 to 72 hours (Figure 1; [14]) and the depth to the groundwater table/potentiometric surface (borehole water level) was measured before the pump started. The dynamic groundwater head was also measured at selected intervals, ranging from 30 seconds and 2 hours at the beginning and lower end respectively, during the pumping period and the time from the moment pumping stopped until full recovery of the static water head as seen via the observation wells (Table 1 and Table 2).

Hydrostratigraphy was used to identify aquifers down to a depth of $350 \mathrm{~m}$ in the study area based on bore hole lithologic logs. Lithologic cross-sections were prepared for each site (Figure 2) and seasonal groundwater head data of the nested observation wells are presented as hydrographs (Figure 3).

The pumping test data were analyzed by several analytical methods and their hydraulic properties were estimated. Among different analytical methods, it is important to select a numerical solution which is appropriate to the actual field conditions, and as suggested by the pattern of the aquifer response to pumping. Different analytical solutions were studied in detail to determine the most appropriate solution to the deep observation well aquifer-test data. For this, some basic assumptions and conditions were considered using different methods valid for confined or leaky-confined aquifers. Theis recovery methods were also applied using analytical solutions. An important assumption is that the pumped well fully penetrates the aquifer and thus receives water from the entire thickness of the aquifer by horizontal flow. If the well only partially penetrates the aquifer, the flow paths have a vertical component to them. The flow paths are, therefore, longer and converge on a shorter well screen, resulting in an increase in head loss [15]. However, observation wells for pumping tests were placed far enough away from the pumping well to avoid partial penetration effects. If the observation well is partially penetrating and its distance from the pumping well is more than 1.5 $b\left(K_{h} / K_{y}\right) 0.5$ (where $b$ is the saturated thickness, and $K_{h}$ and $K_{y}$ are the horizontal and vertical hydraulic conductivities respectively), the effects are negligible [16]. If this condition is not satisfied, there will be an upward inflection in the response, similar to that obtained in the leaky method or for some sort of recharge boundary [17].

\section{Field Setup of the Aquifer Pump Test}

The southern delta plain of the Ganges-Brahmaputra-Meghna delta complex, the Tippera surface and the Chittagong-Cox's Bazar coastal plain dominate the study area. Each of these divisions has distinguishing characteristics of its own. In case of the delta complex, ground elevation increases within the upper reaches of the delta ( $\sim 15$ to $20 \mathrm{~m}$ from sea level in the northwest and 1 to $2 \mathrm{~m}$ in the south). Silty clay, clay, sandy silt with local peat beds are the major constituents of the flood plain, while clay, silty clay and occasionally peat are the major constituent of the delta plain. The dynamic setting in the coastal belt has produced a complex geologic framework for groundwater. Hence, in designing the pumping test and depth of observation wells, the general background of the geology, lithologic conditions and groundwater chemistry have been considered. Lithologic logs of drilled observation wells have been considered to design production tubewells. In order to monitor the response of 


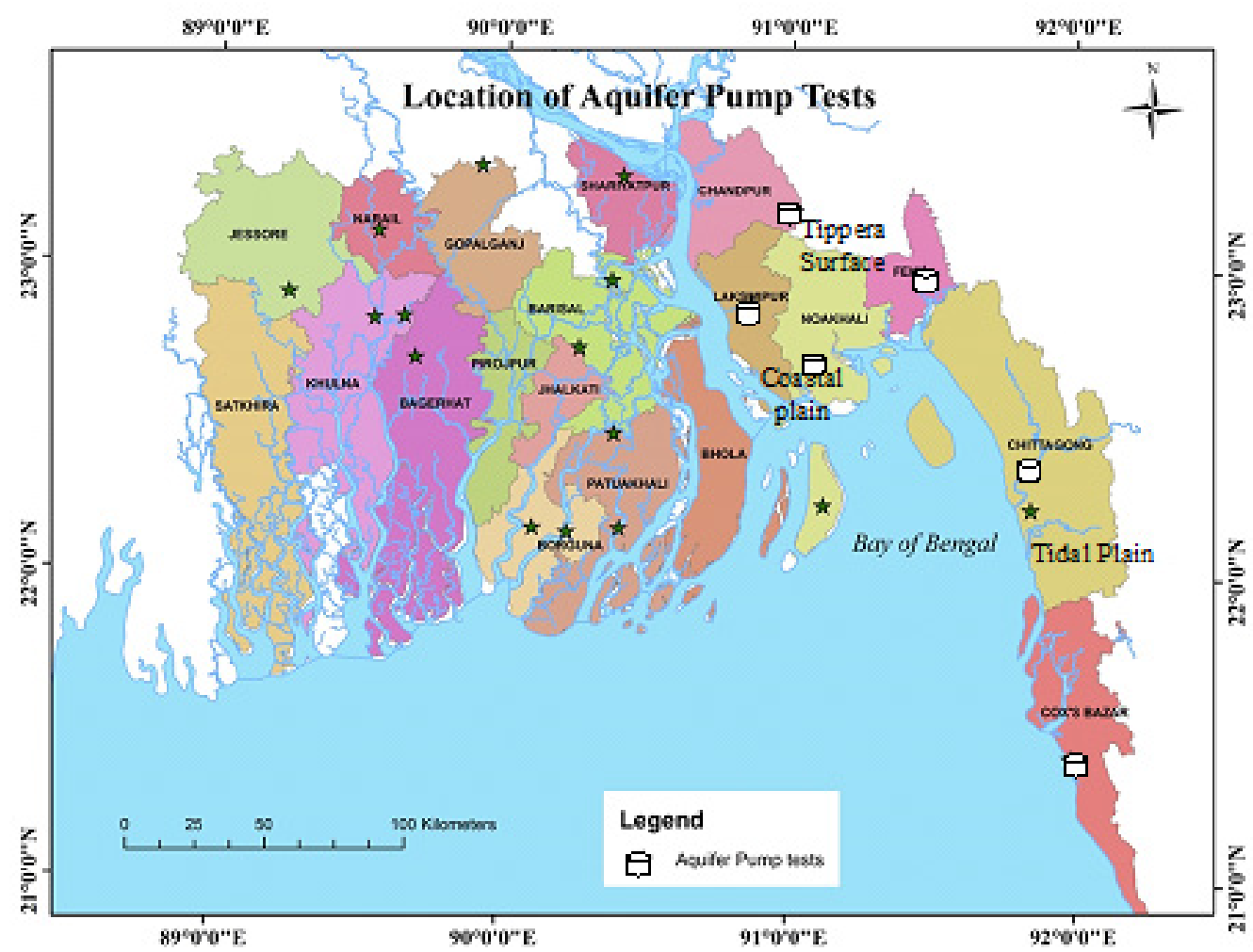

Figure 1: Location map of the deep aquifer pump test sites. Stars indicate the location of pumping tests presented by Zahid et al. [14].

Table 1: Constant discharge aquifer pump test information

\begin{tabular}{|c|c|c|c|c|c|c|c|c|c|}
\hline ID & Location & $\begin{array}{l}\text { Extension of } \\
\text { Deep } \\
\text { Aquifer }(\mathrm{m})\end{array}$ & $\begin{array}{l}\text { Depth of } \\
\text { Pumping } \\
\text { Well (m) }\end{array}$ & $\begin{array}{c}\text { Strainer } \\
\text { Position of } \\
\text { Pumping Well } \\
\text { (m) }\end{array}$ & \begin{tabular}{|c|} 
Duration \\
of Aquifer \\
Pump Test \\
(Hours)
\end{tabular} & $\begin{array}{l}\text { Discharge } \\
\text { (m3/hour) }\end{array}$ & $\begin{array}{c}\text { Distance } \\
\text { of Ob- } \\
\text { servation } \\
\text { Well from } \\
\text { Pumping } \\
\text { Well (m) }\end{array}$ & $\begin{array}{l}\text { Strainer Position of } \\
\text { Observation Well } \\
\text { (m) }\end{array}$ & $\begin{array}{l}\text { Groundwa- } \\
\text { ter Table } \\
\text { before } \\
\text { Pumping } \\
\text { (m) }\end{array}$ \\
\hline \multicolumn{10}{|l|}{ Tidal Delta } \\
\hline LKLKOW-02 & $\begin{array}{l}\text { Laksmipur Sadar, } \\
\text { Laksmipur }\end{array}$ & $256.09-280.48$ & 298.78 & $260.67-286.58$ & 72 & 32.62 & 32 & $271.341-277.43$ & 2.8 \\
\hline \multicolumn{10}{|l|}{ Coastal Plain } \\
\hline CHCHOW-04 & $\begin{array}{l}\text { Chittagong Sadar, } \\
\text { Chittagong }\end{array}$ & $0-222.56$ & 259 & $222.56-253.04$ & 36 & 2.01 & 61 & $210.36-219.51$ & 12.85 \\
\hline CXCXOW-04 & $\begin{array}{l}\text { Cox's Bazar Sadar, } \\
\text { Cox's Bazar }\end{array}$ & $112.80-201.21$ & 195.12 & $137.19-167.68$ & 52 & 15.29 & 31.5 & $189.02-198.17$ & 6.45 \\
\hline \multicolumn{10}{|c|}{ Tippera Surface } \\
\hline CDSROW-03 & $\begin{array}{l}\text { Shahrasti, } \\
\text { Chandpur }\end{array}$ & $9.14-292.68$ & 274 & $237.8-268.29$ & 72 & 64.22 & 31.5 & $280.48-289.63$ & 6.3 \\
\hline FNFNOW-05 & Feni Sadar, Feni & $231.70-243.9$ & 246 & $219.51-243.9$ & 72 & 20.16 & 56.7 & $233.23-242.37$ & 2.95 \\
\hline NKKHOW-05 & Kabirhat, Noakhali & $210.36-231.7$ & 237.84 & $201.21-231.7$ & 52 & 17.31 & 57.5 & $225.60-231.7$ & 4.395 \\
\hline
\end{tabular}


Table 2: Hydraulic properties of deep aquifer sediment based on aquifer pump test analysis

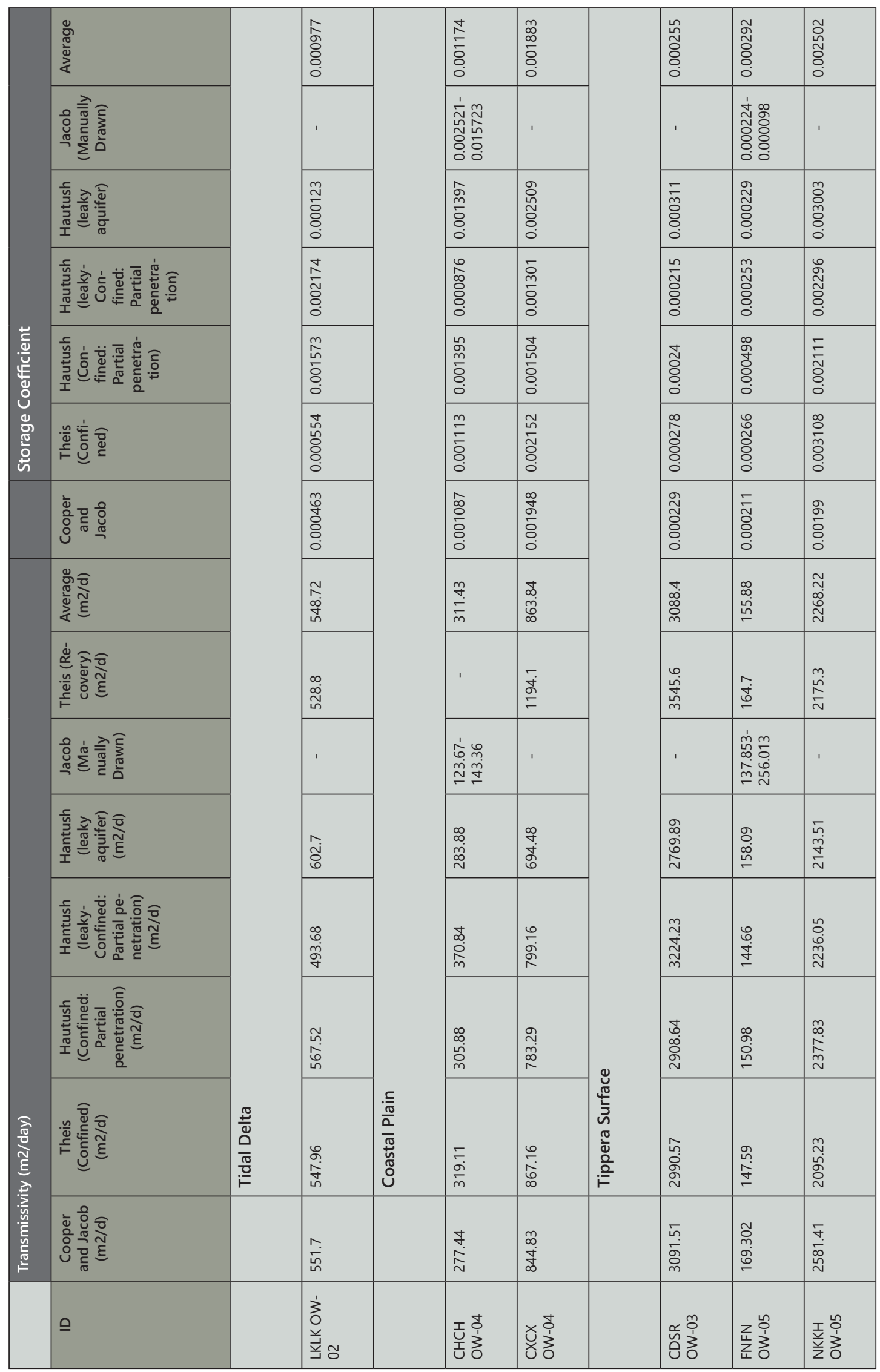


pumping, i.e. to measure drawdown, observation wells were installed both in the pumped aquifer and aquifer units above it. The distance of observation wells from the pumping wells also reflects a basic understanding of the geologic conditions. Short-duration tests may require monitoring wells to be placed closer than those being tested for longer pumping times. The depths of the production i.e. pumping tubewells ranged from 195 to $298 \mathrm{~m}$. The diameter of the production wells was considered as $102 \mathrm{~mm}$ with the housing pipe set at a diameter of $306 \mathrm{~mm}$. The distance of the observation wells used for analysis was between 19 and $73 \mathrm{~m}$ away from the pumping wells for different aquifer tests. Information on six aquifer pump test setups is provided in Table 1. For the completed aquifer pump tests, manual measurements were taken using water level meters. Transducers were also installed to read drawdown data every 30 seconds.

As salinity is a major problem in the study area and occurs at different depths, low to medium well discharge with the ranges between 15.29 and $64.22 \mathrm{~m}^{3} / \mathrm{h}$ were considered for different locations. The electrical conductivity of the discharged water was recorded at certain intervals during pumping to monitor any change in salinity (Figure 4; Table 3).

\section{Results}

\section{Aquifer System and Analysis of Drawdown Data}

In Bangladesh, semi-consolidated to unconsolidated fluvio-deltaic sediments of Miocene to the Present deposited in the Bengal Basin include many aquifers. The aquifer system of the study area has been analyzed on the basis of borehole lithologic logs of nested wells, and production wells. It has been revealed that the distribution of aquifer sediments in the subsurface is very complex due to highly variable alternation of the aquifer-aquitard even within a short distance. While the Bengal Aquifer System has been considered a single interconnected aquifer system at the basin scale [18], at regional and smaller scales discrete aquifer levels may be recognized [19]. Considering lithology of aquifer sediments, BWDB-UNDP [20] has classified the aquifer system of the Bengal Basin as: i) the shallow, ii) the main, and iii) the deep aquifers down to the depth of about 300 $\mathrm{m}$. Aggarwal et al. [11] on the basis of isotopic studies classified the water at different depths into four types and made a three-tier division of the aquifers. BGS-DPHE [21], with slight adjustments of the UNDP [20] study also made a three-tier classification of the aquifer zones i.e. the $1^{\text {st }}$ or Upper-Holocene aquifer, $2^{\text {nd }}$ or Mid-Holocene aquifer and $3^{\text {rd }}$ or Late-Pleistocene to Early-Holocene aquifer. The shallow i.e. the $1^{\text {st }}$ aquifer extends down to 50 to over $100 \mathrm{~m}$, in some places below a considerably thick upper clay and silt unit. The aquifer sediments are composed of fine sand with lenses of clay. The main or $2^{\text {nd }}$ aquifer bearing zones extends down to 250-300 m and is generally underlain and overlain by silty-clay beds and composed mainly of fine to very fine sand with occasional inter-bedded clay lenses. In most areas the upper two aquifers are probably hydraulically interconnected. The deep or $3^{\text {rd }}$ aquifer has been encountered to depths of 300$350 \mathrm{~m}$, separated from the overlying main aquifer by one or more clay layers of varied thickness and extent. This aquifer is composed mainly of gray to dark gray fine sand that in places alternates with thin silty clay or clay lenses. Literature studies elsewhere show that in some areas, deep aquifers are strongly confined, vertical fluxes are negligible and flow is constrained laterally within the aquifer layers. Elsewhere, mixing of water between two aquifers across an aquitard is also noticed, based on the hydraulic gradient, hydrostratigraphy, water chemistry and hydraulic characteristics of the aquifer system [22]-[25], all of which require careful monitoring. This study aims to determine the potential for deep groundwater development in southeastern Bangladesh. A description of the location and area of the aquifer system is given below. The drawdown versus time plot for Theis solution and Cooper and Jacob solution are presented in Figure 5 and Figure 6 respectively.

\section{Laksmipur}

At the Laksmipur study area, which lies on the tidal part of the delta, a single aquifer is identified with a thickness of $225 \mathrm{~m}$ which is overlain by a $60 \mathrm{~m}$ thick aquitard and underlain by a silty clay aquitard up to the drilled depth. The aquifer sediment is dominated by fine gray sand and no significant clay or silty clay layer is noticed in this aquifer system (Figure 2).

One $291 \mathrm{~m}$ deep production well with a $30.5 \mathrm{~m}$ screen length at the bottom and two piezometric observation wells, i.e. OW-1 and OW-2

Table 3: Monitoring of Electrical Conductivity $(\mu \mathrm{S} / \mathrm{cm})$ of groundwater in the pumping production wells during aquifer pump tests

\begin{tabular}{|c|c|c|c|c|c|c|c|c|c|c|c|c|c|}
\hline \multirow{2}{*}{ Location } & \multicolumn{13}{|c|}{ Time interval (hours) after pumping starts } \\
\hline & 0 & 6 & 12 & 18 & 24 & 30 & 36 & 42 & 48 & 54 & 60 & 66 & 72 \\
\hline \multicolumn{14}{|l|}{ Tidal Delta } \\
\hline Laksmipur Sadar, Laksmipur & 296 & 289 & 284 & 282 & 282 & 286 & 282 & 279 & 280 & 277 & 279 & - & - \\
\hline \multicolumn{14}{|l|}{ Coastal Plain } \\
\hline Chittagong Sadar, Chittagong & - & - & - & - & - & - & - & - & - & - & - & - & - \\
\hline Cox's Bazar Sadar, Cox's Bazar & 1000 & 651 & 597 & 573 & 550 & 541 & 539 & 528 & 523 & & & & \\
\hline \multicolumn{14}{|l|}{ Tippera Surface } \\
\hline Shahrasti, Chandpur & 1749 & 1779 & 1791 & 1795 & 1796 & 1798 & 1804 & 1807 & 1809 & 1811 & 1826 & 1815 & 1813 \\
\hline Feni Sadar, Feni & - & - & - & 497 & 433 & 389 & 433 & 488 & 491 & 419 & - & 466 & 420 \\
\hline Kabirhat, Noakhali & 1266 & 1416 & 1435 & 1439 & 1452 & 1462 & 1478 & 1487 & 1493 & - & - & - & - \\
\hline
\end{tabular}


(located 15 and $32 \mathrm{~m}$ away from the main tube well respectively) with depths of 222 and $280 \mathrm{~m}$, respectively, were installed for the purpose of the aquifer pump test at Laksmipur (Figure 2). A 72-hour constant discharge test was conducted until the drawdown reached a steady state. During the aquifer pump test, the initial static water level before the pump was started was measured as $3.07 \mathrm{~m}$ and the maximum drawdown was recorded as $16.88 \mathrm{~m}$ in the pumping well, while total drawdown in OW-2 was recorded as $0.66 \mathrm{~m}$ which was measured both manually and using a data logger (Table 1). The transmissivity value, which is estimated using the drawdown data of OW-2 varied between 493 and $602 \mathrm{~m}^{2} /$ day while values for the storage coefficient (S) varied between 0.000123 and 0.002174 , suggesting that the aquifer might be confined to leaky-confined in nature. The values of $T$ and $S$ calculated using Hantush method give values of $493 \mathrm{~m}^{2}$ / day and 0.002174 , respectively. Using the Theis method for recovery data, T was estimated as $528 \mathrm{~m}^{2} /$ day (Table 2 ). The changes in salinity in the pumping well during the aquifer test were not significant, with $296 \mu \mathrm{S} / \mathrm{cm}$ at the beginning, and $279 \mu \mathrm{S} / \mathrm{cm}$ after 60 hours of extraction (Table 3).

\section{Chittagong City}

In Chittagong City, the well nest was installed at the BWDB office compound, Bohaddarhat, down to the depth of about $280 \mathrm{~m}$. Silty clay and clay lenses were found interbedded within the aquifer up to the investigated depth, with an underlying silty aquitard at 270 $\mathrm{m}$ below the surface. Very fine, fine and medium sand were found in the aquifer. A 2 to $5 \mathrm{~m}$ thick silt and silty clay layer at about 220 $\mathrm{m}$ depth may divide the upper and lower aquifers (Figure 2). Grain size analysis of aquifer sediments from various depths show that the uniformity coefficient values range from 1.66 to 2.75 , indicating a fairly uniform grading of sand.

The groundwater head of five observation wells, i.e. PZ- 1 (OW-1), PZ-2 (OW-2), PZ-3 (OW-3) and PZ-5 (OW-5) with depths of 81, 178, 197, 220 and $233 \mathrm{~m}$, respectively, were monitored to observe the seasonal trend of water levels (Figure 3). To fulfill the demand of water supply for Chittagong city dwellers, the abstraction rate of groundwater from the aquifer was very high. There was also an existing production well for groundwater extraction within $300 \mathrm{~m}$ of the well nest location which may influence the groundwater head values of the monitoring wells throughout the year. The minimum and maximum depths to water from the ground surface was observed at 19.2, 13.9, 13.6 and $13.9 \mathrm{~m}$, and 21.6, 16.1, 14.5 and $14.1 \mathrm{~m}$, respectively for PZ-1, PZ-2, PZ-3 and PZ-4.

The aquifer pump test was conducted using a 259 m deep production well and five piezometric observation wells i.e. OW-1, OW-2, OW3, OW-4 and OW-5 at depths of 81, 178, 197, 220 and $233 \mathrm{~m}$ and distances of $6,13.5,21.5,28.5$ and $61 \mathrm{~m}$, respectively, from the production well (Figure 2). A 36-hour constant discharge test was conducted until the drawdown reached a stable position. The deep observation well i.e. OW-4, installed in the pumping aquifer, was used to measure drawdown; it was located at $61 \mathrm{~m}$ from the pumping production well. During the aquifer pump test, the initial static water level before the pump was started was measured at $12.85 \mathrm{~m}$ and the maximum drawdown was recorded as $25.78 \mathrm{~m}$ in the pumping well, while total drawdown in OW-4 was recorded as $0.08 \mathrm{~m}$, measured both manually and using a data logger (Table 1). For the different methods of calculating transmissivity $(\mathrm{T})$ and the storage coefficient (S), values vary from 123 to $370 \mathrm{~m}^{2}$ /day and from 0.000876 to 0.002521 , respectively. The storage coefficient values indicate that the aquifer should be confined to leaky-confined in nature. The values of T and S calculated using the Hantush method were $370 \mathrm{~m}^{2}$ / day and 0.000876 , respectively (Table 2 ). The change in salinity in the pumping well during the test was not measured at this site as this highly elevated area is not vulnerable to salinity intrusion.

\section{Cox's Bazar Town}

Based on the borelog data, two aquifers were identified in this study area close to the BAEC Kolatoli compound in Cox's Bazar, lying under the Chittagong-Cox's Bazar coastal plain, down to a depth of 330 $\mathrm{m}$. The aquifer system is found from the surface to a depth of 200 $\mathrm{m}$ underlain by thick silty clay and a clay layer to the drilled depth. This restricts the aquifer system to the zone above a depth of $200 \mathrm{~m}$. The $1^{\text {st }}$ or upper aquifer occurs from the ground surface to $100 \mathrm{~m}$, consisting of gray fine sand. At some places the zone has thin lenses of silty clay. The $2^{\text {nd }}$ or main aquifer is encountered between 100 and $200 \mathrm{~m}$ and consists of fine to medium gray sand and is overlain by a silty clay aquitard of about 5 to $10 \mathrm{~m}$ in thickness (Figure 2). Grain size analysis of the aquifer materials shows that the uniformity coefficient ranges between 2 and 2.5, indicating a fairly uniform grading of sand.

At the Cox's Bazar Kolatoli well nest site, groundwater head was measured at four observation wells, PZ-1 (OW-1), PZ-2 (OW-2), PZ-3 (OW-3) and PZ-4 (OW-4) with depths of 25, 92, 139 and 174 $\mathrm{m}$, respectively (Figure 3 ). The seasonal groundwater head data from all piezometers show that the water head starts to decline in August-September and reaches a maximum depth in March-April and then moves upward again in the monsoon season to regain the static water head in July-August. The fluctuations of water head are between 0.7 and $2.5 \mathrm{~m}$. The minimum and maximum depths of the groundwater head were observed as 4.5, 5.0 and $5.9 \mathrm{~m}$ and 7.0, 7.1 and $6.8 \mathrm{~m}$, respectively, for PZ-2, PZ-3 and PZ-4. The minimum and maximum depths of groundwater head for PZ-1 were measured as 2.2 and $5.1 \mathrm{~m}$, respectively. Groundwater extraction by production wells installed in the deep aquifer by many large hotels and others appears to influence the water head at PZ-2 and PZ-3.

A 52-hour constant discharge aquifer pump test was conducted until the drawdown reached a stable position using one production well (174 $\mathrm{m}$ deep) and five piezometers: OW-1, OW-2, OW-3, OW-4 and OW-5 with depths of 25,92, 139, 174 and $200 \mathrm{~m}$ and distances of $4.5,5.5,11.5,31.5$ and $50.5 \mathrm{~m}$ from the production well, respectively. The drawdown data from OW-4, which was installed with a depth close to that of the pumping well, was used for the analysis. During the aquifer pump test, the initial static water level before the pump was started was measured as $5.64 \mathrm{~m}$ and the maximum drawdown was recorded as $13.41 \mathrm{~m}$ in the pumping well, while total drawdown in OW-4 was recorded as $0.12 \mathrm{~m}$, measured both manually and using data logger (Table 1). The different methods for calculating 
transmissivity $(\mathrm{T})$ and the storage coefficient $(\mathrm{S})$ gave values varying from 694 to $867 \mathrm{~m}^{2} /$ day and from 0.002151 to 0.002509 , respectively. The values of $S$ suggest that the aquifer should be confined to semiconfined in nature. The Hantush method gave the values of $\mathrm{T}$ and $\mathrm{S}$ as $799 \mathrm{~m}^{2} /$ day and 0.001301 , respectively (Table 2 ). The changes in salinity in the pumping well during the aquifer test were within the limit of potable water with $1000 \mu \mathrm{S} / \mathrm{cm}$ initially and $523 \mu \mathrm{S} / \mathrm{cm}$ after 50 hours (Table 3 ).

\section{Chandpur}

The study site is located at Shahrasti in the Chandpur district which lies on the Tippera surface. In this investigated area, silty clay aquitard about $5 \mathrm{~m}$ in thickness is found at the surface, underlain by the aquifer that extends up to the investigated depth of $320 \mathrm{~m}$. The aquifer sediment consists of very fine and fine gray sand with medium sand lenses at various depths. Very thin silty clay lenses are also observed within the aquifer (Figure 2). Aquifer sediments from various depths show that the uniformity coefficient ranges from 1.92 to 3.33 , indicating a fairly uniform grading of sand.

The groundwater head at three observation wells, i.e. PZ-1 (OW1), PZ-2 (OW-2) and PZ-3 (OW-3) with depths of 70, 177 and 292 $\mathrm{m}$, respectively, was monitored at the Shahrasti upazila well nest site (Figure 3). Seasonal groundwater table data of all piezometers show that the water head starts to decline in December and reaches a maximum depth in March-April and then moves upward again in monsoon season to regain the static water head in OctoberNovember. The fluctuations in the groundwater head are between 0.7 and $2.5 \mathrm{~m}$. Minimum and maximum depths to the groundwater head were observed as 1.5, 2.2 and $2.1 \mathrm{~m}$ and 4.5, 7.1 and $6.8 \mathrm{~m}$, respectively for $\mathrm{PZ}-1, \mathrm{PZ}-2$ and $\mathrm{PZ}-3$.

A 72-hour constant discharge aquifer pump test was conducted at Shahrasti until the drawdown reached a stable position. Four piezometers, OW-1, OW-2, OW-3 and OW-4 with depths of 70, 177,292 and $317 \mathrm{~m}$, and a production well with a depth of $274 \mathrm{~m}$ were used to conduct the test. The distances of the piezometers from the production well were $3.7,7.5,31.5,73.5 \mathrm{~m}$, respectively . The drawdown data from OW-3, which was installed in the pumping aquifer, were selected for the analysis. During the aquifer pump test, the initial static water level before the pump was started was measured as $6.28 \mathrm{~m}$ and the maximum drawdown was recorded as $13.55 \mathrm{~m}$ in the pumping well, while total drawdown in OW-3 was recorded as $0.17 \mathrm{~m}$, measured both manually and using a data logger (Table 1). The different methods for calculating transmissivity (T) and the storage coefficient (S) gave values varying from 2769 to $3224 \mathrm{~m}^{2} /$ day and from 0.000229 to 0.000311 , respectively. The Hantush method gave the values of $T$ and $S$ as $3224 \mathrm{~m}^{2} /$ day and 0.000215 , respectively. Using the Theis method for recovery data, $\mathrm{T}$ was estimated as $3545 \mathrm{~m}^{2} /$ day (Table 2). The storage coefficient values indicate that the aquifer should be confined to leaky-confined in nature. The changes in salinity in the pumping well during the aquifer test were not significant, with $1749 \mu \mathrm{S} / \mathrm{cm}$ after 2 hours and $1813 \mu \mathrm{S} / \mathrm{cm}$ after 72 hours (Table 3 ).

\section{Laskarhat, Feni}

Four aquifers have been identified in the investigated location at Motobi Munshi Bari in Laskarhat under the Feni district, down to the investigated depth of $280 \mathrm{~m}$. The thickness of the aquifer units varies between 5 and $30 \mathrm{~m}$ and they are interbedded with thick aquitards of silty clay layers. The upper or $1^{\text {st }}$ aquifer is encountered at depths from 20 to $50 \mathrm{~m}$ below the surface, overlain by 20 to $30 \mathrm{~m}$ thick clay and a silty clay aquitard. The aquifer sediment consists of fine sand with medium sand lenses. The $2^{\text {nd }}$ or main aquifer occurs at depths from 80 to $120 \mathrm{~m}$, consisting of light brown fine to very fine sand, overlain by a silty clay aquitard around $55 \mathrm{~m}$ thick. At places, this zone has thin lenses of silty clay. Underlying the main aquifer there is a deeper water-bearing unit which is referred to as the $3^{\text {rd }}$ or deep aquifer. This water-bearing zone is separated from the overlying main aquifer by $40 \mathrm{~m}$-thick silty clay and clay layers. The $3^{\text {rd }}$ aquifer consists of gray medium to fine sand and occurs at depths from 160 to $180 \mathrm{~m}$. The $4^{\text {th }}$ aquifer consists of gray to light brown medium to fine sand overlain by a $17 \mathrm{~m}$-thick aquitard. This water-bearing zone occurs at depths from 200 to $260 \mathrm{~m}$ (Figure 2). The grain size analysis of the aquifer materials indicates that the deep aquifer is fairly uniform, with uniformity coefficient values ranging between 1.54 and 2.29.

The groundwater head at four observation wells, PZ-1 (OW-1), PZ-2 (OW-2), PZ-3 (OW-3) and PZ-4 (OW-4) with depths of 45, 127, 182 and $246 \mathrm{~m}$ respectively, was monitored at the Laskarhat well nest site under Feni sadar (Figure 3). Seasonal groundwater head data from piezometers show that the water head starts to decline in October at PZ-1 and in December at PZ-2, PZ-3 and PZ-4 and reaches the maximum depth in April before starting to rise again. The fluctuations in the water heads are between 2.0 and $2.8 \mathrm{~m}$. Fluctuation is lowest at PZ-4. The minimum and maximum depths of groundwater head from the surface were observed as 1.7, 2.6, 2.6 and $1.1 \mathrm{~m}$ and 4.6, 4.65, 4.65 and $2.7 \mathrm{~m}$, respectively for PZ-1, PZ-2, PZ-3 and PZ-4. The groundwater head is highest at the deepest piezometer, PZ4 , throughout the year, compared to the water heads of the other piezometers, i.e. 4.2 and $5.4 \mathrm{~m}$ above mean sea-level during dry and wet seasons, respectively. This indicates that the deep or $4^{\text {th }}$ aquifer is hydraulically separated from the aquifer units above.

A 72-hour constant discharge aquifer pump test was conducted at Laskarhat using one production well with a depth of $246 \mathrm{~m}$ and five piezometers, OW-1, OW-2, OW-3, OW-4 and OW-5 with depths of $45,127,182,246$ and $258 \mathrm{~m}$ and distances of 3, 5, 8, 26 and $57 \mathrm{~m}$ from the production well, respectively. During the aquifer pump test, the initial static water level before the pump was started was measured as $2.95 \mathrm{~m}$ and the maximum drawdown was recorded as $4.94 \mathrm{~m}$ in the pumping well, while total drawdown in OW-5 was recorded as 1.99 $\mathrm{m}$, measured both manually and using a data logger (Table 1). The different methods for calculating transmissivity $(T)$ and the storage coefficient (S) gave values varying from 137 to $256 \mathrm{~m}^{2} /$ day and from 0.000224 to 0.000098 , respectively. The Hantush method gave the values of $T$ and $S$ as $144 \mathrm{~m}^{2} /$ day and 0.000253 , respectively (Table 2). Using the Theis method for recovery data, $T$ was estimated at 164 $\mathrm{m}^{2} /$ day. The values of $\mathrm{S}$ suggest that the aquifer should be confined 
to leaky-confined in nature. The changes in salinity in the pumping well during the aquifer test were not significant, with $497 \mu \mathrm{S} / \mathrm{cm}$ after 22 hours and $420 \mu \mathrm{S} / \mathrm{cm}$ after 72 hours (Table 3 ).

\section{Kabirhat, Noakhali}

In the Ghoshbag area of Kabirhat, the aquifer system can be divided into five units. A set of $300 \mathrm{~m}$-deep boreholes were drilled in the study area under the Tippera surface. The aquifers are separated by silty clay and silt layers. The $1^{\text {st }}$ or upper aquifer is exposed to the ground surface and extends to a depth of about $30 \mathrm{~m}$; it consists of very fine sand. This aquifer is underlain by thick silty clay and a silt aquitard about $13 \mathrm{~m}$ thick. Below the $1 \mathrm{st}$ aquifer, the $2^{\text {nd }}$ or main aquifer is found, consisting of gray very fine to fine sand. This aquifer extends from 45 to $70 \mathrm{~m}$ and is overlain by a thick aquitard. Below the $2^{\text {nd }}$ aquifer, a $40 \mathrm{~m}$-thick aquitard is found and consists of silty clay and silt layers. This aquitard extends from 70 to $110 \mathrm{~m}$ below the surface. The $3^{\text {rd }}$ aquifer is found at depths of 110 to $145 \mathrm{~m}$. It consists of very fine gray sand and is confined to leaky-confined in nature, whist being underlain and overlain by aquitards. Below the third aquifer the thickness of the aquitard is about $15 \mathrm{~m}$. This aquitard extends from 145 to $160 \mathrm{~m}$ and consists of a silty clay layer. At depths of 160 to $240 \mathrm{~m}$ the $4^{\text {th }}$ aquifer is found. It is stratified with gray colored very fine sand, fine sand and a silty clay layer. The thickness of this aquifer is about $80 \mathrm{~m}$, underlain by a $15 \mathrm{~m}$-thick silty clay layer. The $5^{\text {th }}$ aquifer is found at depths of 255 to $295 \mathrm{~m}$ and consists of a layer of fine gray sand. This water-bearing zone is underlain by a silty aquitard and separated from the $4^{\text {th }}$ aquifer by a $15 \mathrm{~m}$-thick silty clay aquitard (Figure 2).

The groundwater head at the four observation wells, PZ-1 (OW1), PZ-2 (OW-2), PZ-3 (OW-3), PZ-4 (OW-4) and PZ-5 (OW-5) with depths of 27, 137, 195, 234 and $298 \mathrm{~m}$, respectively, was monitored at the Kabirhat well nest site in the Noakhali district (Figure 3). Seasonal groundwater head data from all piezometers show that the water head starts to decline in September and reaches its maximum depth in April before moving upwards again in monsoon season to regain a static water head in July-August (Figure 3). The fluctuation of the water head is about $3.0 \mathrm{~m}$ at PZ-1 and 1.2 at PZ-2, PZ-3 and PZ-4. The minimum and maximum depths of the groundwater head from the surface were observed as 0.4 and $3.0 \mathrm{~m}$ for PZ-1 and PZ-2, and $3.4 \mathrm{~m}$ and $4.2 \mathrm{~m}$ for PZ-3 and PZ-4, respectively. The trend of water head fluctuation implies that PZ-2, PZ-3 and PZ-4 are hydraulically connected and separate from the upper aquifer i.e. PZ-1.

At Kabirhat, a 52-hour constant discharge aquifer pump test was conducted until the drawdown reached a stable position. Five piezometers were used: OW-1, OW-2, OW-3, OW-4 and OW-5, with depths of 27, 137, 195, 234, and $298 \mathrm{~m}$ and distances of 4.5, 8.5, 12.5, 19 and $57.5 \mathrm{~m}$ from the production well, respectively. The depth of the pumping production well was $235 \mathrm{~m}$. During the aquifer pump test, initial static water level before the pump was started was measured as $4.58 \mathrm{~m}$ and the maximum drawdown was recorded as $14.38 \mathrm{~m}$ in the pumping well, while total drawdown in OW-5 was recorded as 0.09 $\mathrm{m}$, measured both manually and using a data logger (Table 1). The different methods for calculating transmissivity $(T)$ and the storage coefficient (S) gave values varying from 2095 to $2581 \mathrm{~m}^{2} /$ day and from 0.001199 to 0.003003 , respectively. The Hantush method gave values of T and S as $2236 \mathrm{~m}^{2} /$ day and 0.002296 , respectively. Using the Theis method for recovery data, T was estimated as $2175 \mathrm{~m}^{2}$ / day (Table 2). The values for the storage coefficient suggest that the aquifer is confined to leaky-confined in nature. The changes in salinity in the pumping well during the aquifer test were not significant, with $1266 \mu \mathrm{S} / \mathrm{cm}$ initially and $1493 \mu \mathrm{S} / \mathrm{cm}$ after 48 hours (Table 3). 

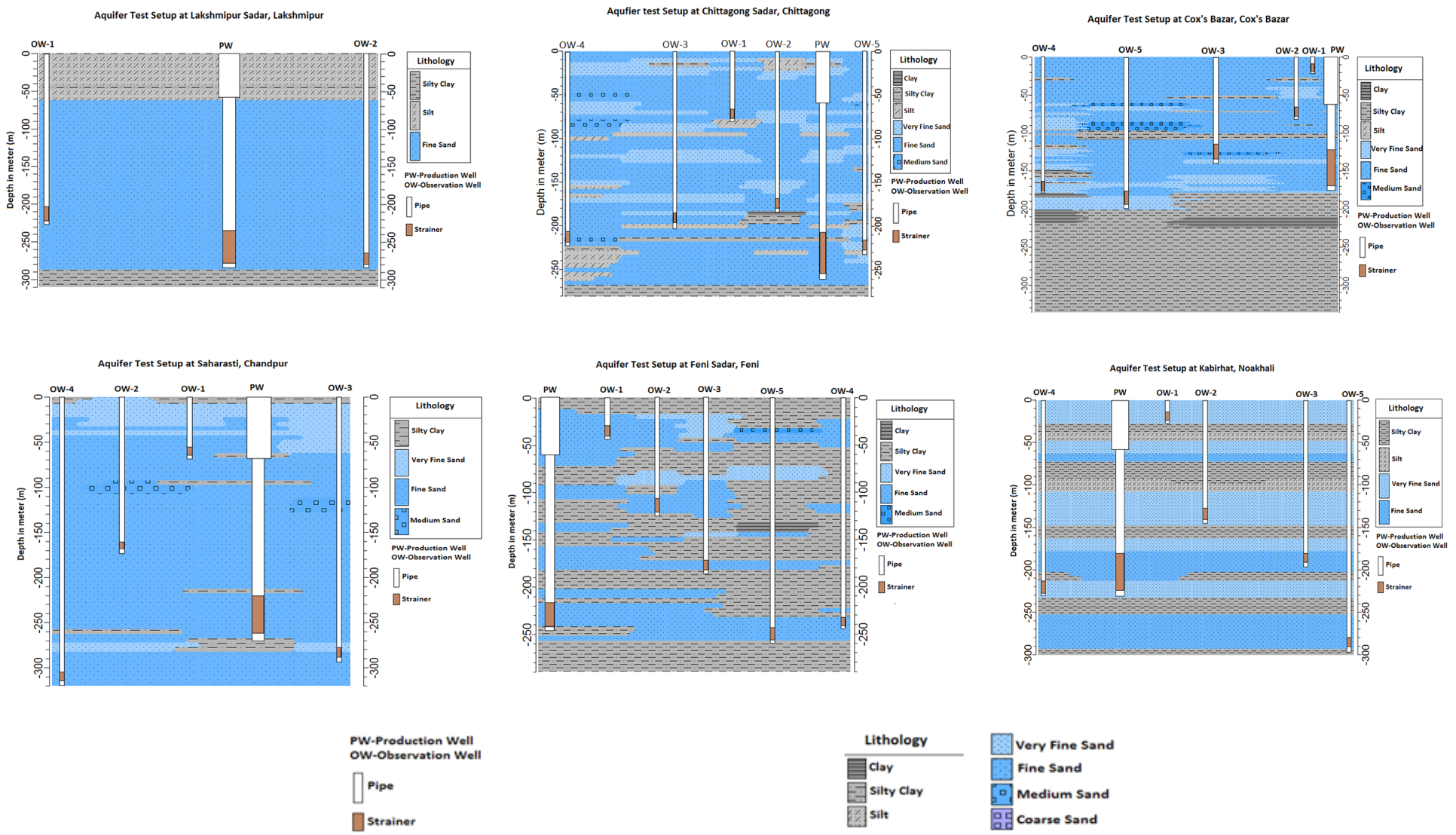

Figure 2: Lithologic cross-sections with the design of the aquifer pump test setup.
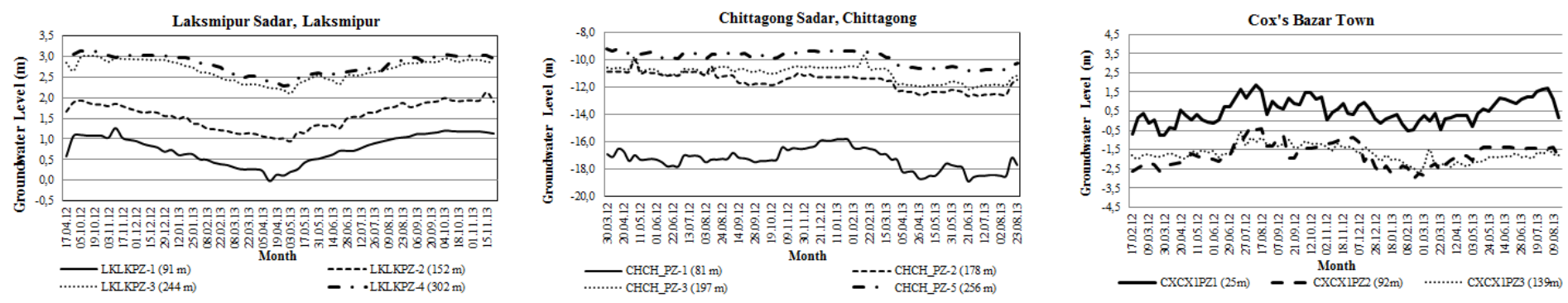

Tidal Delta

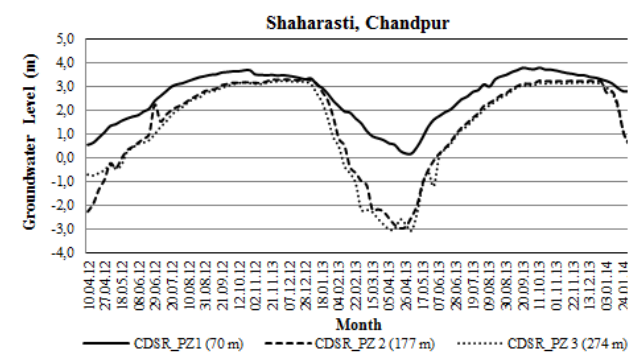

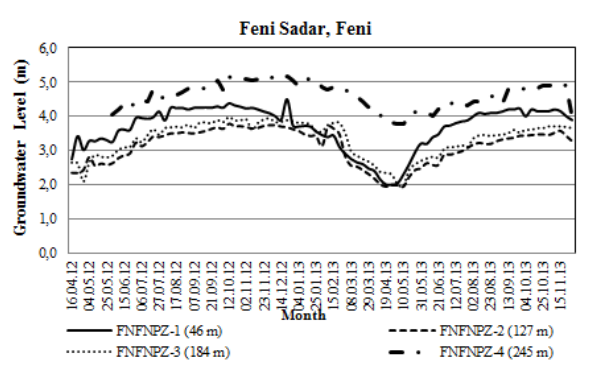

Coastal Plain

\section{Tippera Surface}

Figure 3: Variation in groundwater head (with respect to MSL) of the nested observation wells in 2012-2013, installed at different depths at the study sites. 


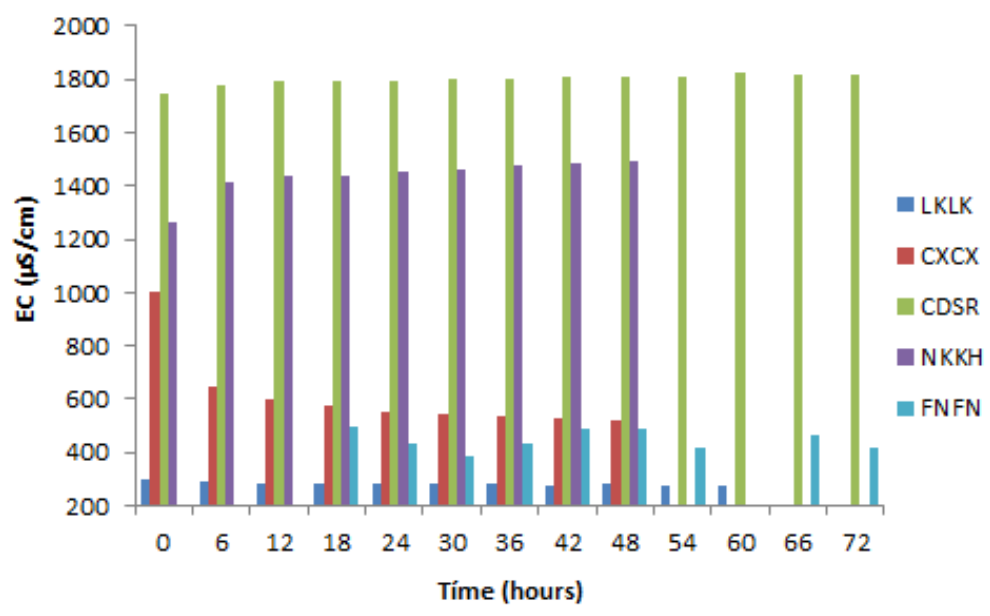

Figure 4: 'EC vs. Time' showing hourly change (at 6 hours intervals) in electrical conductivity of the groundwater samples from pumping wells tapped in the deep aquifers.

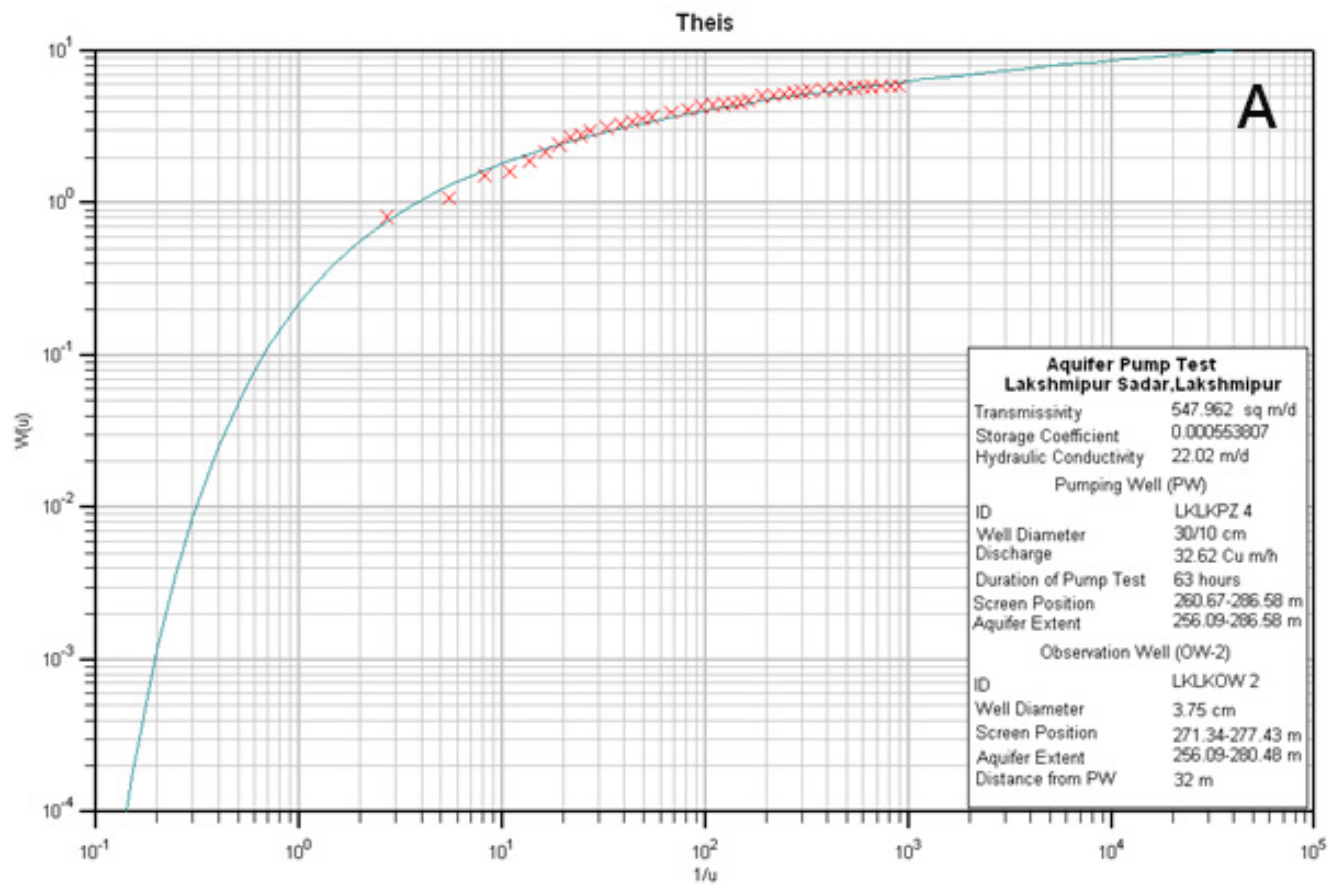



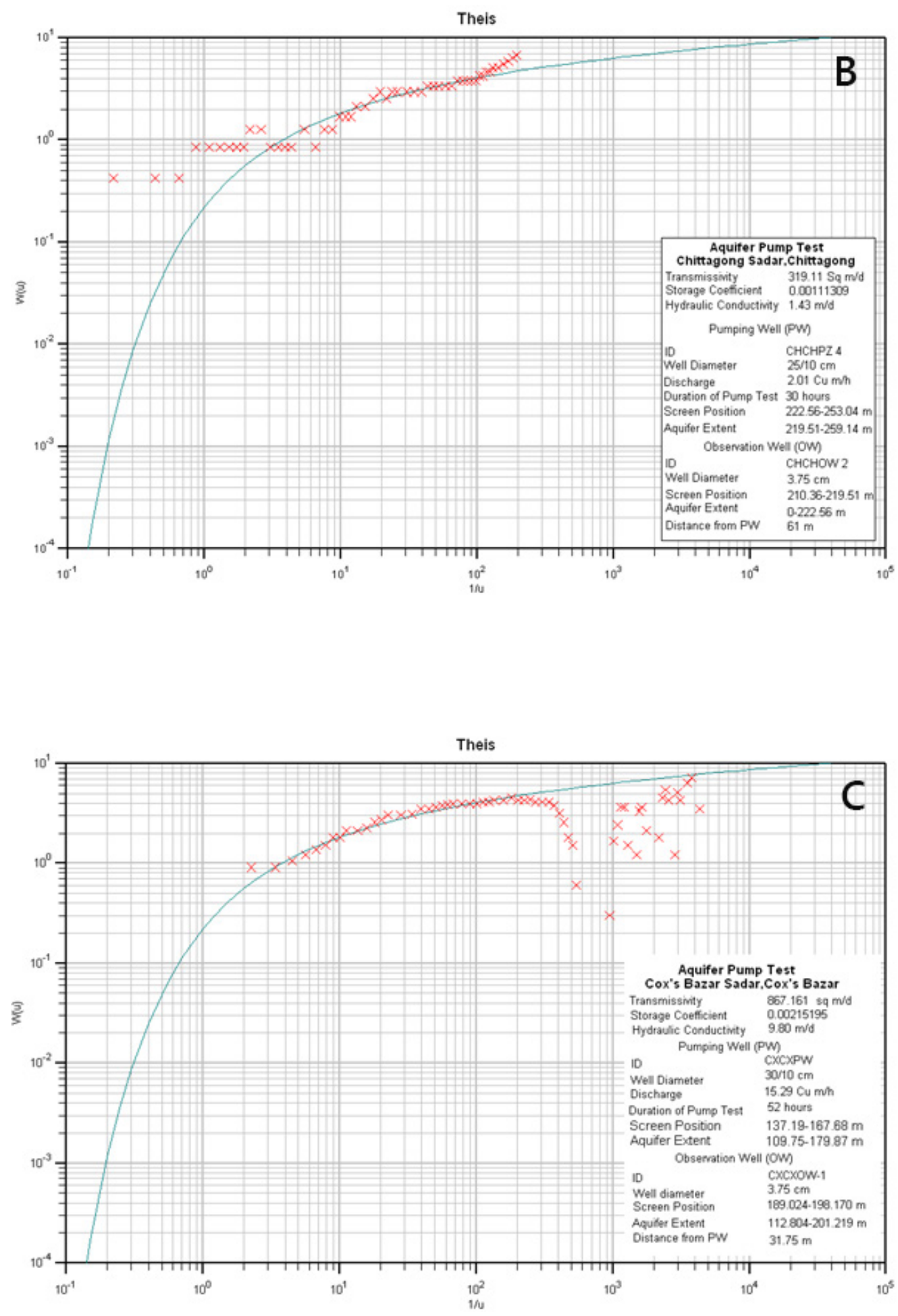

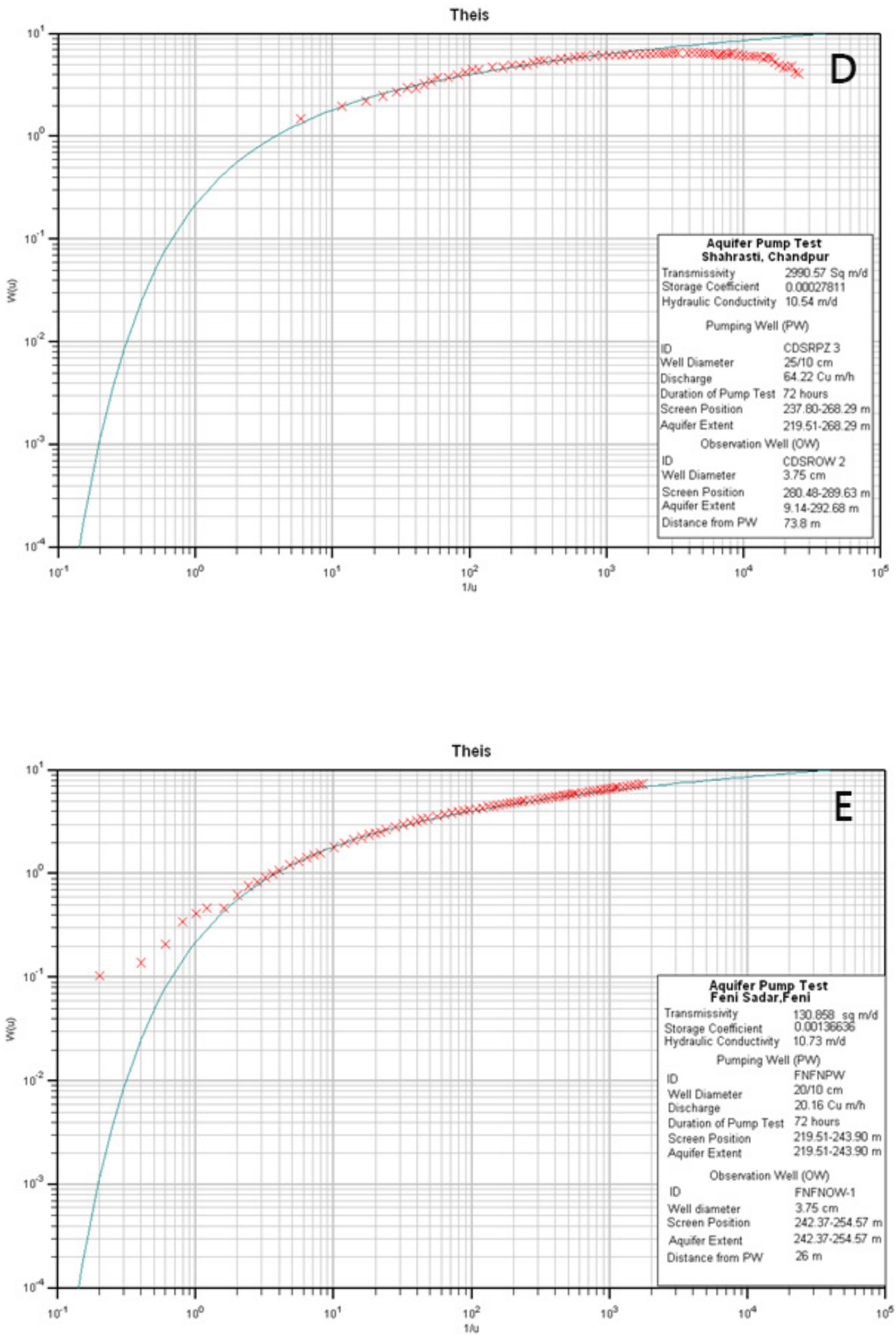


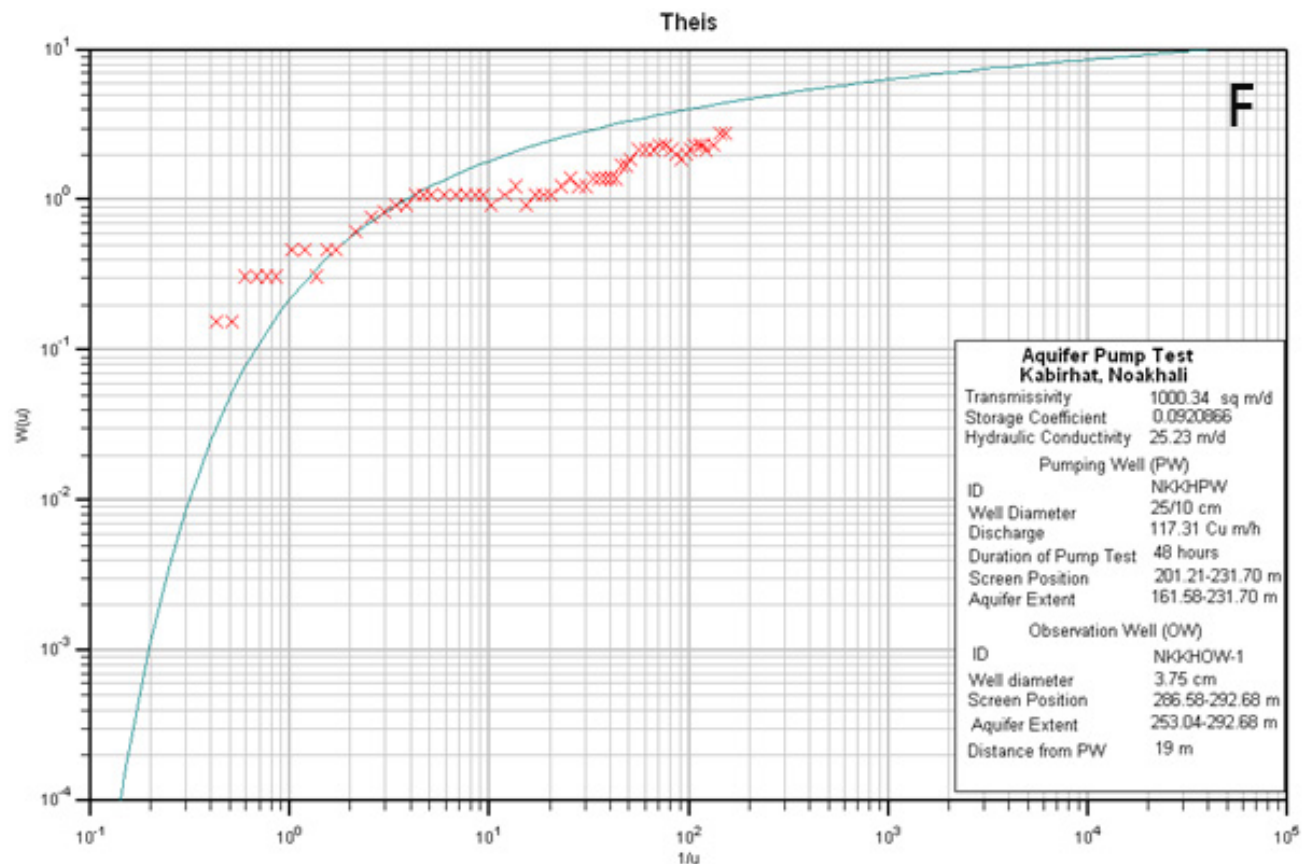

Figure 5: Drawdown versus time plot using double logarithmic scales for Theis solution. (A) Laksmipur Sadar; (B) Chittagong; (C) Cox's Bazar; (D) Chandpur; (E) Feni; (F) Noakhali.

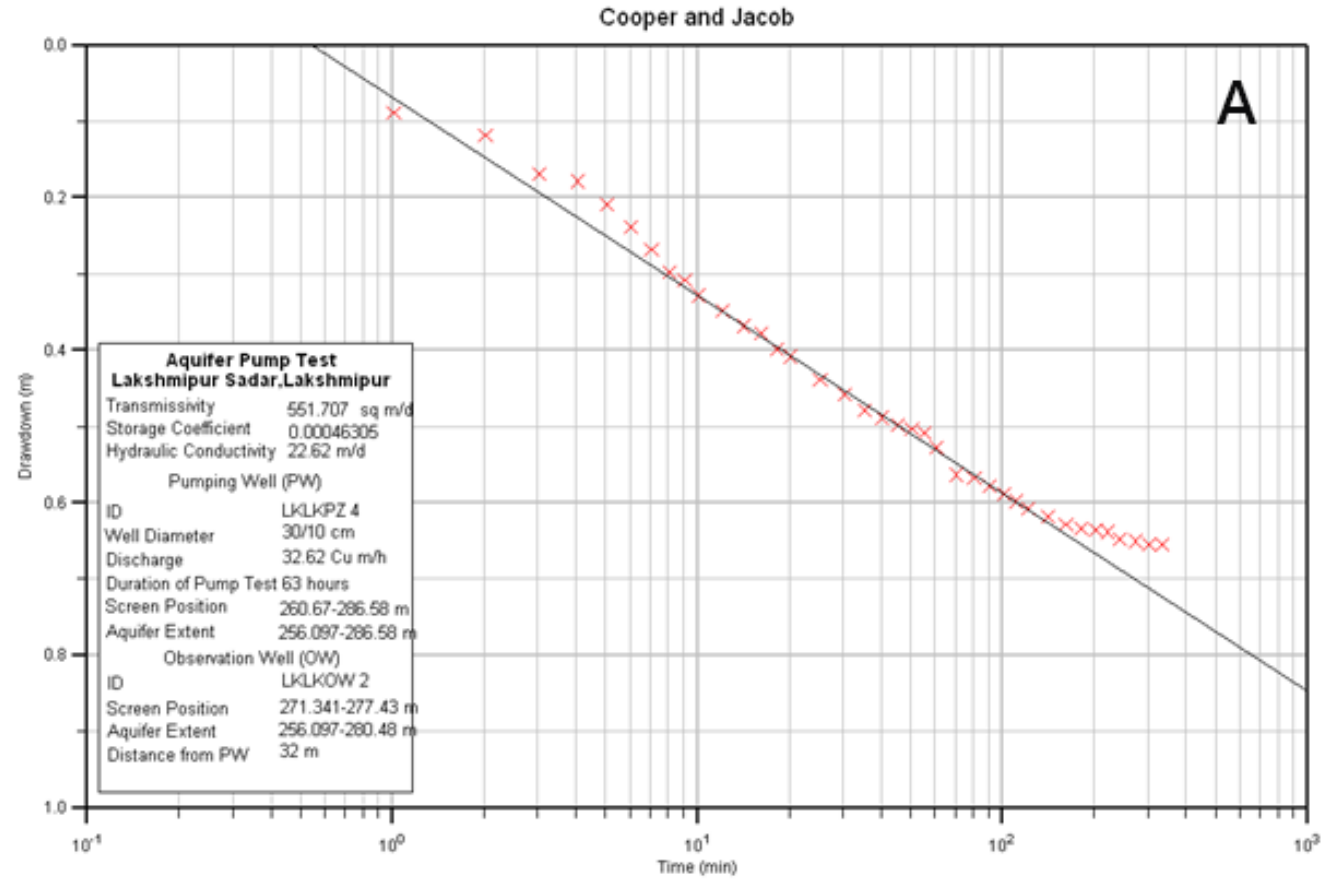



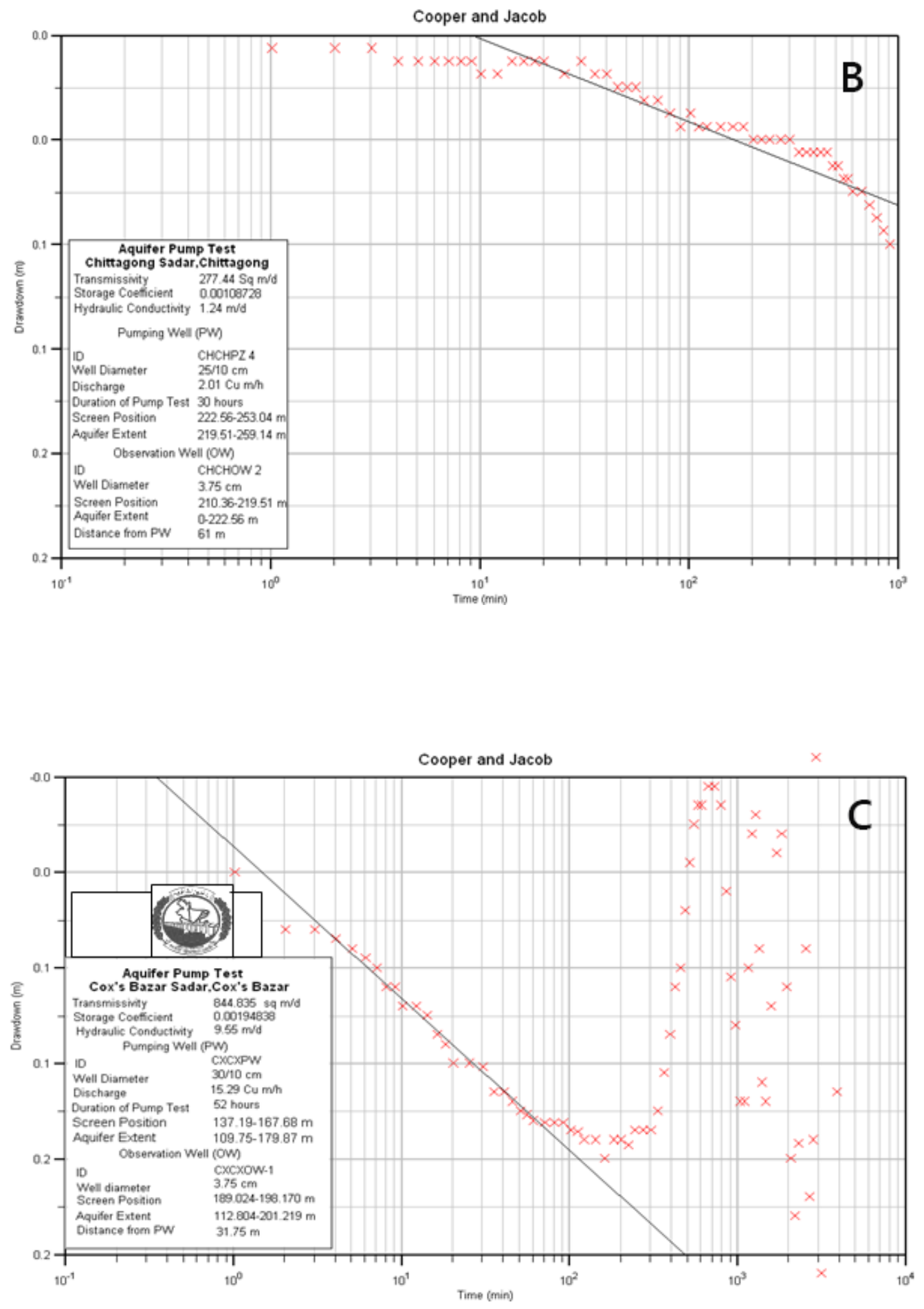

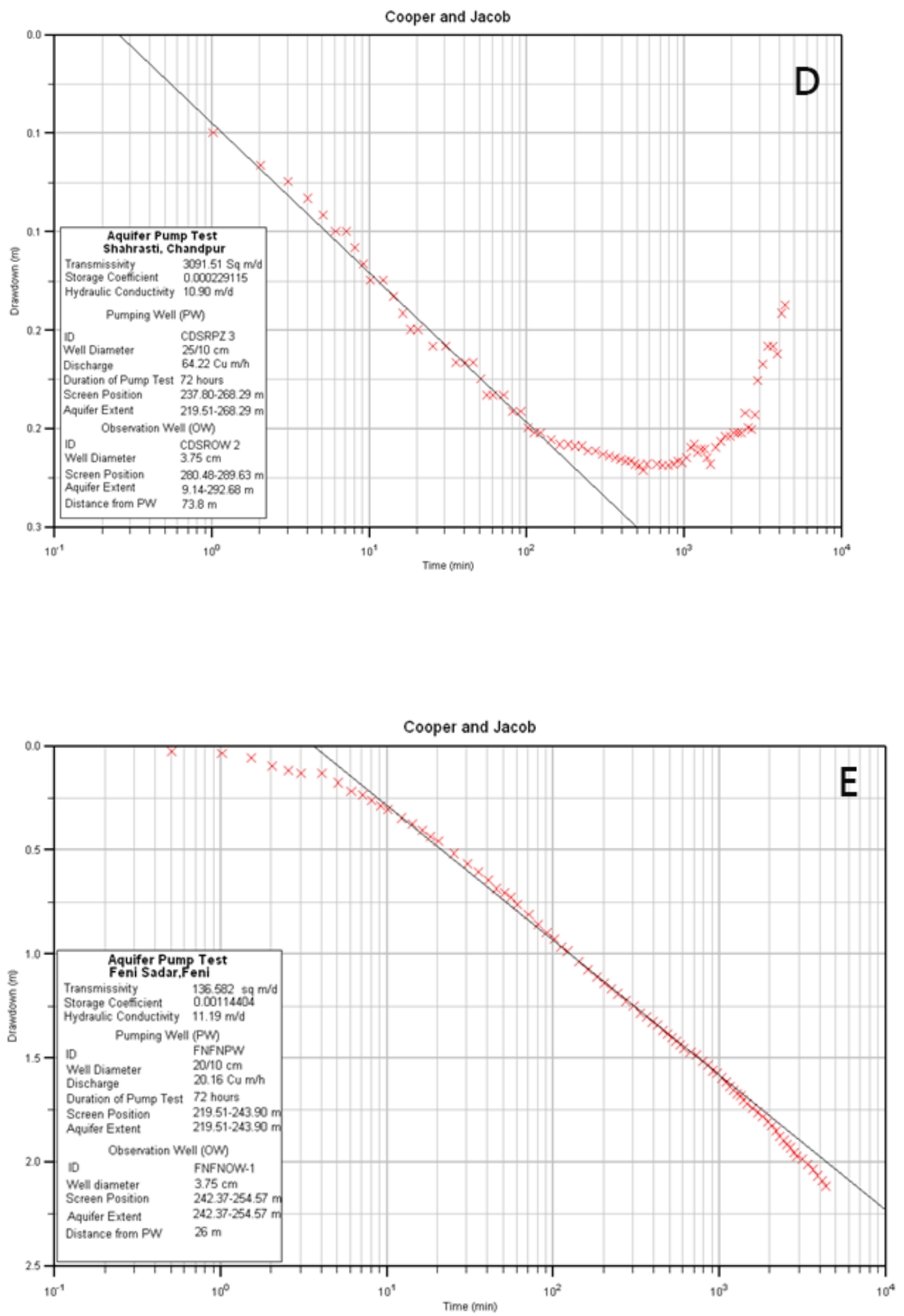


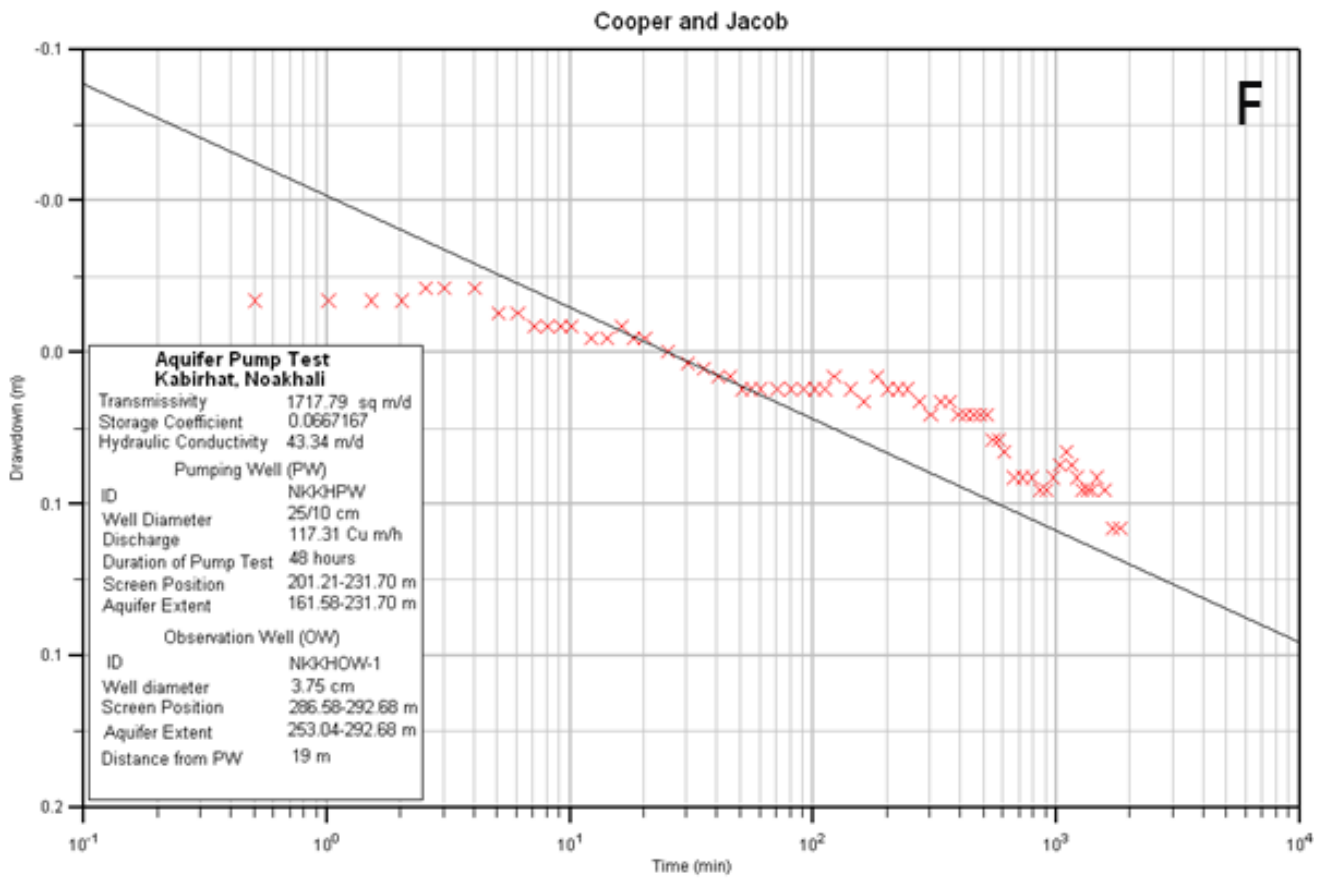

Figure 6: Linear drawdown versus logarithm of time plot for Cooper and Jacob solution. (A) Laksmipur Sadar; (B) Chittagong; (C) Cox's Bazar; (D) Chandpur; (E) Feni; (F) Noakhali.

\section{Discussion}

As geological processes do not deposit sediments uniformly, aquifers commonly differ in their hydraulic properties at different locations. From the aquifer pump tests conducted in the deep aquifers in question in this study, using drawdown data for different classical methods applicable for confined, leaky-confined or leaky aquifers, transmissivity (T) was calculated between 123 and $3545 \mathrm{~m}^{2} / \mathrm{d}$. This high variable range of $\mathrm{T}$ values is generally due to the variable degree of sorting in aquifer sediments and the thickness of aquifer units, which is consistent with the lithological data as well as the sources of recharged groundwater. Aquifer characteristics are heterogeneous and isotropic as sediments range from coarse channel fill to silt due to varying patterns of deposition in coastal and alluvial environments [26]. Appropriate methods need to be applied to the analysis of the pump test data depending on the particular type of aquifer. Complicated aquifer geometry sometimes produces a timedrawdown curve that can be analyzed using different equations. In that case an average of the parameter values can be accepted. In order to minimize well losses and partial penetration effects on $T$ values as well as considering leaky-confined to confined characteristics of most of the tested aquifers, the Cooper-Jacob method is the best solution for the aquifers in question. The aquifer pumping test results show that the groundwater heads decline rapidly at the early stage of pumping, in most cases up to 200 min, except for the observation wells at Laskarhat (OW-5) and OW-4 at Cox's Bazar, where the fall in water heads continued until the end of the test (4000-4500 min) with discharge rates of 20.16 and $15.29 \mathrm{~m}^{3} / \mathrm{h}$, respectively. Beyond the stage of early rapid drawdown, the water heads for the different locations showed variable responses with the variable pumping rate (2.0-64.22 $\left.\mathrm{m}^{3} / \mathrm{h}\right)$ and for different geological settings. In addition, the duration of the pumping, the distance of the observation wells from the pumping well, the lithologic conditions, i.e. position and thickness of the overlying aquitards, the aquifer type, source of recharged water, and other factors, may be expected to influence the rate of drawdown. The groundwater head at Cox's Bazar (OW-4) began to fluctuate after 300 min from the start of pumping due to tidal influence, since this observation well tapped into the upper shallow aquifer located near shore (Figure 2). However, at Kabirhat, Noakhali, no significant drop in the groundwater head was observed in the upper aquifers, suggesting this upper shallow unconfined aquifer is not affected by pumping from the deep aquifer as there is an impermeable layer between them (Figure 2). Similarly, drawdown data for observation well (OW-5) shows a rapid drop in the groundwater head up to 300 min followed by an erratic water head until the end of the test (2000 min). At Chittagong City (OW-4), the groundwater head becomes stable within $100 \mathrm{~min}$ and again starts to fall after a stable phase from 100 to 500 min. The groundwater head at Shahrasti, Chandpur reached a stable phase at $200 \mathrm{~min}$ and began to raise after a stable phase from 200 to $1000 \mathrm{~min}$, with a discharge rate of $64.22 \mathrm{~m}^{3} / \mathrm{h}$. At Laksmipur (OW-2), the groundwater head reached a stable phase after 2500 min of pumping. 
The erratic occurrence of small fresh water pockets at depth is reported all over the coastal belt. Under extensive exploitation, operation of a well tapping into a deep aquifer depends on the replenishment from outside of the aquifer system. At the early stage of the pumping tests, the extracted groundwater comes from the release of the storage of the aquifer (as in the Theis assumptions for a confined aquifer [27]). During the following stages the leakage from the upper aquifer increases as the difference in water heads occurs between the two aquifers [28]. The release of the aquifer storage declines as the flow field created by the pumping test reaches a steady state [28]. The area of influence of an observation well drawdown is generally bounded by an ellipse that encloses the pumping well and the observation well [29]. The duration of pumping during the aquifer tests was between 36 and 72 hours and drawdown was recorded between 0.08 and 1.99 $\mathrm{m}$ with more than $0.5 \mathrm{~m}$ drawdown at Laksmipur (OW-2) and Feni (OW-5), while less than $0.2 \mathrm{~m}$ was observed at Chittagong (OW-4), Cox's Bazar (OW-4), Chandpur (OW-3), and Noakhali (OW-5). A study in the Paris Basin [30] shows that hydraulic connections between all layers may exist in the sedimentary basin, even at depth. However, no drawdown of water levels was seen in the observation wells installed in upper aquifers above the clay or silty clay layers, suggesting that with limited and regulated extraction of groundwater from the deep aquifers in the study area, saline water is unable to reach the deep fresh groundwater units except where there is no significant aquitard between the pumping aquifer and upper contaminated aquifers. At Laksmipur, Cox's Bazar and Feni, the electrical conductivity values for the groundwater changed insignificantly with time during pumping of deep water within the fresh water limit $(<1000 \mu \mathrm{S} / \mathrm{cm})$. In all other cases, the electrical conductivity level remained almost the same within the fresh and brackish water limit $(1000$ and $2000 \mu \mathrm{S} / \mathrm{cm}$, respectively) even after 72 hours of pumping (Table 3 ). However, the electrical conductivity values for all the pumping wells did not vary significantly during the 72 hours of pumping (Figure 4).

Despite the above, windows could occur in the confined clay and, under some conditions, could cause significant saltwater intrusion to the pumping well. Studies show that downward movement of water can occur from a shallow aquifer to an aquitard and from the aquitard to a deep aquifer due to the reduction in head [31] or due to a leaky protective clay layer. The major part of the leakage occurs during the pumping period while small portions occur as residual leakage after pumping has stopped. Therefore, the aquitards separating the deep aquifer from the saline upper aquifers in the coastal belt of the Bengal Delta could protect the fresh deep groundwater, even in some places where a protective clay layer is absent. Although large-scale extraction of deep groundwater for irrigation is not recommended, proper and planned use for domestic purposes is considered safe. Model study [9] for the lower delta shows that aquifers are recharged by vertical percolation as well as by water from long distance travel from highly elevated eastern hilly areas mainly to deeper aquifers. Large scale groundwater pumping for irrigation together with other extraction from the upper aquifers tends to retard vertical percolation into deeper aquifers, resulting in increased travel time in the deep aquifer units. The average travel time, i.e. the age of water for the deep aquifer has been dated as about hundreds to thousands of years [9] at different geologic conditions. . However, many previous studies show that water from the upper shallow aquifer may percolate downward into the deeper fresh water zones through aquitard windows. The effect of saltwater intrusion depends on the lateral distance between windows in the clay and the well [32].

The values of different aquifer parameters also differ considerably when different methods are used to analyze the same data. Depending on the accuracy of the graph preparation and subjective judgments in matching field data to type curves there is often slight variation in the results [33]. The accuracy of the numerical values of the hydraulic characteristics of aquifers and aquitards determined during the graphical analyses and the accuracy of the assumed boundary conditions play an important role in the reliability of the results obtained by these methods. But in some circumstances, it has not been possible to determine the aquifer type from the shape of the time-drawdown curve and thus, the appropriate equation to analyze the data. Hence, the average values of the parameters determined by different methods can be considered as the most acceptable values. The average $T$ is calculated between 155.88 and $3088.4 \mathrm{~m}^{2} /$ day for different locations with a median value of $1622.14 \mathrm{~m}^{2} /$ day. $T$ was also calculated for recovery data, ranging from 164.7 to $3545.6 \mathrm{~m}^{2}$ / day. Transmissivity values from recovery data were, in most cases, calculated higher than $T$ values computed from the time-drawdown data. Research has found that recovery data are more reliable for estimating hydraulic properties [34]. The T values estimated for the central and south-west coast of the tidal Bengal Delta range between 557.81 and $2956.69 \mathrm{~m}^{2} /$ day for different locations [14].

The different values of $\mathrm{T}$ suggest that the aquifer differs in terms of hydraulic conductivity and thickness in different parts of the study area. The Chittagong and Feni deep aquifers show low potential with $T$ ranges between 123.67 and $370.84 \mathrm{~m}^{2} /$ day, while high potential aquifers with T ranges between 2095.23 and 3545.6 $\mathrm{m}^{2}$ /day were estimated for the Chandpur and Noakhali aquifers. Others show moderate values in terms of their transmissivity with ranges between 493.68 and $1194.1 \mathrm{~m}^{2} /$ day. When $\mathrm{T}$ is estimated using the Theis curve method and the Cooper-Jacob method, they are generally comparable [35]. In order to minimize well losses and partial penetration effect on T values, the Cooper-Jacob method is the best solution. Additional drawdown at later times during the aquifer pump test is due to declining heads in the aquifer and the rate of decline is controlled mostly by the aquifer's T value [36]. Small-scale variations in hydraulic conductivity around the wells where the measurements are taken cause different $T$ values in nearby wells [37]. Where there was more than one observation well in the pumping test, the drawdown for different observation wells installed in the pumping aquifer were found to differ, with the nearest one having the highest value and furthest one the lowest drawdown, as expected. In this case, the smallest values are selected to determine the optimal pumping duration.

Calculated average $S$ values ranged from 0.000255 to 0.002502 , indicating that the aquifers are confined to leaky-confined in nature [33], [38]. For Cox's Bazar, S was calculated between 0.0013 and 0.002508 , which are common values for semi-confined to confined aquifers [35]. Estimated average $S$ values for the deep aquifers under 
the central and south-west coast of the Bengal Delta, excluding the Khulna aquifer, range from 0.00011 to 0.006644 [14].

\section{Summary}

During the aquifer pumping tests, no drawdown of water heads was seen in the observation wells installed in upper aquifers above the clay or silty clay layers. This is suggesting that with limited and regulated extraction of groundwater from the deep aquifers in the study area, saline water would not reach the deep fresh groundwater units except where there is no significant aquitard between the pumping aquifer and the upper contaminated aquifers. Electrical conductivity values for all the pumping wells did not vary significantly during the aquifer pumping tests. It was also found that the distribution of aquifer sediments in the subsurface of the southeastern coast is very complex due to highly variable alternation of aquifer-aquitard, even within a short distance. This high variable range of $T$ values is consistent with the lithological data for the aquifer. Beyond the stage of early rapid drawdown, groundwater heads for different locations showed variable responses with the variable pumping rate (2.0-64.22 $\mathrm{m}^{3} / \mathrm{h}$ ) and for different geological settings. Besides these, the duration of the pumping rate, the distance of the observation wells from the pumping well, the lithologic conditions, i.e. position and thickness of the overlying aquitards, the aquifer type, the source of recharged water, among other factors, all influence the rate of drawdown.

In order to minimize the effects of well losses and partial penetration on $\mathrm{T}$ values, the Cooper-Jacob method is the best solution for the studied aquifers. Based on the T values, the Chittagong and Feni deep aquifers show low potential with T ranges between 123.67 and 370.84 $\mathrm{m}^{2} /$ day, while high potential aquifers with T ranges between 2095.23 and $3545.6 \mathrm{~m}^{2} /$ day were estimated for the Chandpur and Noakhali aquifers. The storage co-efficient values indicate that the aquifers are confined to leaky-confined in nature, except for the aquifer at the BAEC Kolatoli compound, in Cox's Bazar, which is confined to semi-confined in nature. Maintaining proper well spacing, under moderate discharge rate i.e. up to $65 \mathrm{~m}^{3} / \mathrm{h}$, a few hours of pumping per day can be done for potable water supply. Irrigation extraction of groundwater from the deep aquifers is not recommended.

It may be mentioned that, if intensive exploitation of these aquifers were to continue in the future, the water head may not be fully restored, and groundwater quality may ultimately become inadequate. To improve groundwater management programs in these aquifers, it is essential to gain more knowledge and monitor their performance.

\section{Acknowledgment}

Bangladesh Climate Change Trust (BCCT) under the Ministry of Environment and Forest, Bangladesh Water Development Board (BWDB) and Institute of Water Modelling (IWM) are highly acknowledged for supporting the research under the Climate Change Trust Fund project to assess coastal water resources. Hydrogeologists of the project team are acknowledged for their participation in the field aquifer pump test activities.

References

[1] A. Zahid, K. Jahan, M. H. Ali, N. Ahmed, M. K. Islam and A. Rahman, A, "Distribution of groundwater salinity and its seasonal variability in the coastal aquifers of Bengal Delta," in Impact of Climate Change on Socio-economic Conditions of Bangladesh. DAAD, GIZ, AvH Foundation and AAGUB, 2013, pp. 170-193.

[2] A. Zahid, M. Q. Hassan, G. N. Breit, K.-D. Balke, and M. Flegr, "Accumulation of iron and arsenic in the Chandina alluvium of the lower delta plain, Southeastern Bangladesh," Environ. Geochem. Hlth., vol. 31, no. S1, pp. 69-84, Dec. 2008. Doi: https://doi.org/10.1007/s10653-008-9226-1

[3] A. I. Calderhead, R. Therrien, A. Rivera, R. Martel, and J. Garfias, "Simulating pumping-induced regional land subsidence with the use of InSAR and field data in the Toluca Valley, Mexico," Adv. Water Resour., vol. 34, no. 1, pp. 83-97, Jan. 2011. Doi: https://doi.org/10.1016/j.advwatres.2010.09.017

[4] M. V. Esteller, R. Rodríguez, A. Cardona, and L. Padilla-Sánchez, "Evaluation of hydrochemical changes due to intensive aquifer exploitation: case studies from Mexico," Environ. Monit. Asses., vol. 184, no. 9, pp. 5725-5741, Oct. 2011. Doi: https://doi.org/10.1007/s10661-011-2376-0

[5] V. Re, S. Cissé Faye, A. Faye, S. Faye, C. B. Gaye, E. Sacchi, and G. M. Zuppi, "Water quality decline in coastal aquifers under anthropic pressure: the case of a suburban area of Dakar (Senegal)," Environ. Monit. Assess., vol. 172, no. 1-4, pp. 605-622, Mar. 2010. Doi: https://doi.org/10.1007/s10661-010-1359-x

[6] F. La Vigna, S. Ciadamidaro, R. Mazza, and L. Mancini, "Water quality and relationship between superficial and ground water in Rome (Aniene River basin, central Italy)," Environ. Earth Sci., vol. 60, no. 6, pp. 1267-1279, Aug. 2009. Doi: https://doi.org/10.1007/s12665-009-0267-2

[7] J. J. Carrillo-Rivera, A. Cardona, R. Huizar-Alvarez, and E. Graniel, "Response of the interaction between groundwater and other components of the environment in Mexico," Environ. Geol., vol. 55, no. 2, pp. 303-319, Sep. 2007. Doi: https://doi. org/10.1007/s00254-007-1005-2

[8] J. A. Barker and A. R. Lawrence, "A simple model of leakage induced by deep pumping and its application to pollution beneath a city in Thailand," Hydrogeol. J., vol. 16, no. 3, pp. 407-417, Mar. 2008. Doi: https://doi.org/10.1007/s10040-008$\underline{0277-2}$

[9] A. Zahid, M. Q. Hassan, and K. M. U. Ahmed, "Simulation of flowpaths and travel time of groundwater through arsenic-contaminated zone in the multi-layered aquifer system of Bengal basin," Environ. Earth Sci., vol. 73, no. 3, pp. 979-991, Jul. 2014. Doi: https://doi.org/10.1007/s12665-014-3447-7

[10] D. J. Lapworth, A. Zahid, R. G. Taylor, W. G. Burgess, M. Shamsudduha, K. M. Ahmed, A. Mukherjee, D. C. Gooddy, D. Chatterjee, and A. M. MacDonald, "Security of deep groundwater in the coastal Bengal basin revealed by tracers," Geophys. Res. Lett., Aug. 2018. Doi: https://doi.org/10.1029/2018gl078640

[11] P. Aggarwal, A. Basu, R. Poreda, K. M. Kulkarni, K. Froehlich, S. A. Tarafdar, M. Ali, N. Ahmed, A. Hussain, M. Rahman, S. R. Ahmed, "A report on isotope hydrology of groundwater in Bangladesh: Implications for characterization and mitigation of arsenic in groundwater,". Int. Atomic Energy Agency, Dept. of Tech. Co-operation, Vienna (Austria), 2000.

[12] M. A. Hoque and W. G. Burgess, "14C dating of deep groundwater in the Bengal Aquifer System, Bangladesh: Implications for aquifer anisotropy, recharge sources and sustainability," J. Hydrol., vol. 444-445, pp. 209-220, Jun. 2012. Doi: https://doi. org/10.1016/j.jhydrol.2012.04.022

[13] P. Ravenscroft, J. M. McArthur, and M. A. Hoque, "Stable groundwater quality in deep aquifers of Southern Bangladesh: The case against sustainable abstraction," 
Sci. Total. Environ., vol. 454-455, pp. 627-638, Jun. 2013. Doi: https://doi. org/10.1016/j.scitotenv.2013.02.071

[14] A. Zahid, M. H. Ali, M. R. Hassan, K. Islam, N. Ahmed, N. Sultana, "Assessment of the deep groundwater security in the Bengal Delta by conducting aquifer pumping tests," Water Utility Journal, no. 15, pp. 29-43, 2017.

[15] F. G. Driscoll, Groundwater and Wells, 2nd edition, St. Paul, MN: U.S. Filter/Johnson Screens, 1995.

[16] M. S. Hantush, "Hydraulics of wells," Adv. Hydrosci., 1964. Doi: https://doi. org/10.1016/b978-1-4831-9932-0.50010-3

[17] P. A. Domenico and F. W. Schwartz, Physical and Chemical Hydrogeology, 2nd edition, New York : John Wiley and Sons Inc, 1997.

[18] H. A. Michael and C. I. Voss, "Controls on groundwater flow in the Bengal Basin of India and Bangladesh: regional modeling analysis," Hydrogeol. J., vol. 17, no. 7, pp. 1561-1577, Feb. 2009. Doi: https://doi.org/10.1007/s10040-008-0429-4

[19] W. G. Burgess, M. A. Hoque, H. A. Michael, C. I. Voss, G. N. Breit, and K. M. Ahmed, "Vulnerability of deep groundwater in the Bengal Aquifer System to contamination by arsenic," Nat. Geosci., vol. 3, no. 2, pp. 83-87, Jan. 2010. Doi: https://doi. org/10.1038/ngeo 750

[20] UNDP, " The hydrogeological condition of Bangladesh. Groundwater survey technical report DP/UN/BGD-74-0071," United Nation Development Programme, New York, 1982.

[21] BGS and DPHE, "Arsenic contamination of groundwater in Bangladesh," British Geological Survey Rep. WC/00/19, Rapid investigation phase, Final rep., 2001.

[22] M. Petitta, "Hydrogeology of the middle valley of the Velino River and of the S. Vittorino Plain (Rieti, Central Italy)," Italian J. Eng. Geology and Environment, no. 1, pp. 157-181, 2009. Doi: https://doi.org/10.4408/IJEGE.2009-01.0-09

[23] A. Baiocchi, F. Lotti, and V. Piscopo, "Impact of groundwater withdrawals on the interaction of multi-layered aquifers in the Viterbo geothermal area (central Italy)," Hydrogeol. J., vol. 21, no. 6, pp. 1339-1353, Jun. 2013. Doi: https://doi.org/10.1007/ $\underline{\text { s10040-013-1000-5 }}$

[24] A. Baiocchi, F. Lotti, and V. Piscopo, "Conceptual hydrogeological model and groundwater resource estimation in a complex hydrothermal area: The case of the Viterbo geothermal area (central Italy)," J. Water Resour. Prot., vol. 04, no. 04, pp. 231-247, 2012. Doi: https://doi.org/10.4236/jwarp.2012.44026

[25] M. Petitta, P. Primavera, P. Tuccimei, and R. Aravena, "Interaction between deep and shallow groundwater systems in areas affected by Quaternary tectonics (Central Italy): a geochemical and isotope approach," Environ. Earth Sci., vol. 63, no. 1, pp. 11-30, Jul. 2010. Doi: https://doi.org/10.1007/s12665-010-0663-7

[26] J. B. Gates, J. P. Nicot, B. R. Scanlon, and R. C. Reedy, "Arsenic enrichment in unconfined sections of the southern Gulf Coast aquifer system, Texas," Appl.
Geochem., vol. 26, no. 4, pp. 421-431, Apr. 2011. Doi: https://doi.org/10.1016/j. apgeochem.2011.01.002

[27] G. P. Kruseman and N. A. de Ridder Analysis and evaluation of pumping test data, The Netherlands: International Institute for Land Reclamation and Improvement/ ILRI, 1983.

[28] Z. Xun, C. Mingyou, F. Bin, Z. Hua, S. Ye, and Y. Jinmei, "An analysis of the inferaquifer recharge for a deep-seated aquifer system tapped by a wellfield," Environ. Geol., vol. 51, no. 4, pp. 647-653, Jun. 2006. Doi: https://doi.org/10.1007/s00254$\underline{006-0360-8}$

[29] D. S. Oliver, "The influence of nonuniform transmissivity and storativity on drawdown," Water Resour. Res., vol. 29, no. 1, pp. 169-178, Jan. 1993. Doi: https:// doi.org/10.1029/92wr02061

[30] C. Contoux, S. Violette, R. Vivona, P. Goblet, and D. Patriarche, "How basin model results enable the study of multi-layer aquifer response to pumping: the Paris Basin, France," Hydrogeol. J., vol. 21, no. 3, pp. 545-557, Feb. 2013. Doi: https://doi. org/10.1007/s10040-013-0955-6

[31] X. Chen, Y. Yin, J. W. Goeke, and R. F. Diffendal, "Vertical movement of water in a High Plains Aquifer induced by a pumping well," Environ. Geol., vol. 47, no. 7, pp. 931-941, Feb. 2005. Doi: https://doi.org/10.1007/s00254-005-1223-4

[32] J. Cai, T. Taute, and M. Schneider, "Saltwater upconing below a pumping well in an inland aquifer: A theoretical modeling study on testing different scenarios of deep saline-groundwater pathways," Water, Air, Soil Pollut., vol. 225, no. 11, Oct. 2014. Doi: https://doi.org/10.1007/s11270-014-2203-7

[33] C. W. Fetter, Applied Hydrogeology. Englewood Cliffs, N.J.: Prentice Hall 1994.

[34] K. E. Murray and L. S. Yosko, "Multi-observation well aquifer test case study: is recovery coincident with the cessation of pumping?," Environ. Earth Sci., vol. 68, no. 7, pp. 1955-1965, Aug. 2012. Doi: https://doi.org/10.1007/s12665-012-1883-9

[35] W. D. Weight and J. L. Sonderegger, Manual of Applied Field Hydrogeology. London: McGraw-Hill, 2000.

[36] K. J. Halford and E. L. Kuniansky, "Documentation of spreadsheets for the analysis of aquifer-test and slug-test data," Open-File Report, 2002. Doi: https://doi. org/10.3133/ofr02197

[37] B. B. Dykaar and P. K. Kitanidis, "Transmissivity of a heterogeneous formation," Water Resour. Res., vol. 29, no. 4, pp. 985-1001, Apr. 1993. Doi: https://doi. org/10.1029/93wr00004

[38] J. W. Bower, L. H. Motz, and D. W. Durden, "Analytical solution for determining the critical condition of saltwater upconing in a leaky artesian aquifer," J. Hydrol., vol. 221, no. 1-2, pp. 43-54, Aug. 1999. Doi: https://doi.org/10.1016/s00221694(99)00078-5 